\title{
Characterization of Marketing and Management System of Indigenous Chicken Ecotypes in Awi Zone, Ethiopia
}

\author{
Andualem Yihun ${ }^{1}$, Manzoor Ahmed Kirmani ${ }^{2}$, Meseret Molla ${ }^{3}$ \\ ${ }^{1}$ Department of Animal Science, College of Agriculture, Oda Bultum University, Chiro, Ethiopia \\ ${ }^{2}$ Department of Animal Science, College of Agriculture and Veterinary Medicine, Jimma University, Jimma, Ethiopia \\ ${ }^{3}$ Department of Animal Science, College of Agriculture and Natural Resource, University of Gonder, Gonder, Ethiopia
}

Email address:

andualemyihun95@gmail.com (A. Yihun),Kirmanima@gmail.com (M. A. Kirmani), meseretmo@gmail.com (M. Molla)

\section{To cite this article:}

Andualem Yihun, Manzoor Ahmed Kirmani, Meseret Molla. Characterization of Marketing and Management System of Indigenous Chicken Ecotypes in Awi Zone, Ethiopia. International Journal of Agricultural Economics Vol. 5, No. 6, 2020, pp. 264-278.

doi: $10.11648 /$ j.ijae.20200506.15

Received: October 23, 2020; Accepted: November 4, 2020; Published: November 19, 2020

\begin{abstract}
The study was conducted in three districts of Awi zone in Amhara region, with the aim of managemental system of indigenous chicken ecotypes. Atotal of 180 households were participated in the interviews, which was conducted using a structured questionnaire. The most dominant chicken production system was a subsistence extensive system which is based on indigenous chickens with scavenging and supplementary feeding of home grown grains and household food refusals. In this study the Scavenging was the major feeding system in all districts. About $85 \%, 93.33 \%$ and $78.33 \%$ of the respondents in high-land, mid-land and low-land agro-ecologies practiced scavenging with supplementary feeds respectively. The age of cockerels at first mating and pullets at first egg laying were 5.21 months and 5.77 months, respectively. The results of the rankings had shown that diseases outbreaks mainly Newcastle (locally called wotetie) disease and together with predators were the major and economically important constraint for the existing chicken rearing system. In conclusion, there is diversity of indigenous chicken population and farmers' preference of different traits that may invite to design community based selection criteria. And these were recommended in poultry breeding policy which focused on managemental system, selection, and trait preference should be designed.
\end{abstract}

Keywords: Indigenous, Flock Composition, Husbandry Practice, Selection, Trait Preference

\section{Introduction}

Poultry is the largest livestock group in the world estimated to be about 23.39 billion, consisting mainly of chickens, ducks and turkeys [1]. Ethiopia is believed to have the largest livestock population. According to central statistical agency [2], there are about 56.53 million chickens in Ethiopia, comprising of $94.31,3.21$ and $2.49 \%$ of indigenous, hybrid and exotic types, respectively. In Ethiopia, most chicken populations are non-descriptive type. However, they showed a great variation in their production performance, which might be due to their wide spread distribution and adaptive response to different ecological conditions [3, 4].

Farmers in Africa gave these chicken names like; family chickens, bush chickens or African hen [5]. Besbes et al. stated that family chickens, are reared by families to get food, income and employment [6]. Local chickens contribute significantly to the livelihood of the rural farmers by providing them with high-quality animal protein in the form of eggs and meat for family consumption [7]. Food security ensures that members of a household have access to an enough diet to lead an active and normal life [8].

Improvement of local chicken productivity through selection and cross breeding is vital for all developing countries especially for Ethiopia since there is dynamic increment of human population and incompatibility of demand - supply in animal source foods. Developing appropriate animal breeding programs for village conditions requires characterizing local chickens, defining the production environments and identifying the breeding practices, production objectives, and trait choices of rural farmers [9]. 
Given the highest potential for poultry production and presence of diverse ecotypes, it is imperative to conduct comprehensive studies to characterize morphological, functional, and adaptive traits of local chickens, identifying farmers breeding practices, and trait preference of local chicken producers in the study districts. Therefore, the objective of this study was to designed with managemental system of indigenous chicken Ecotypes in Awi Zone Ethiopia.

\section{Materials and Methods}

\subsection{Brief Description of the Study Areas}

The study was conducted in Faggeta lekoma, Dangila and Zigom districts of Awi Zone based on their altitude classification into three agro-ecologies of Awi zone, Amhara regional state, Ethiopia. The administrative centre of Awi zone is Injibara; other towns include Chagni, Adis kidame, jawi, gimjabet, ----Dangila. Topographically, Awi zone is relatively flat: the altitude of the zone ranges from as low as 550 to 3100 m.a.s.1 the Minimum and maximum annual temperature ranges between $5^{\circ} \mathrm{C}$ and $27^{\circ} \mathrm{C}$. Daily temperature becomes very high during the months of March to May. Average mean annual rainfall for the area is about $1700 \mathrm{~mm}$.

The Zone is crossed by about nine permanent rivers which drain into the Blue Nile; Awi Zone has Two crater lakes namely, Zengena and Tirba. Awi zone has 1,231,447 cattle, 676,509 sheep, 162,576 goats, 206,035 equine (Horse $96,136$, Donkey 93,052 , mule 16,667$), 1,151,708$ poultry and
128,906 bee colonies [2]. The Samples were conducted from three districts, Faggeta lekoma, Dangila and Zigom.

Sample Size Determination and Sampling Techniques

The study was conducted in Faggeta lekoma, Dangila and Zigom districts of Awi zone.

Purposive sampling was employed to select districts based on distribution of chicken population and Agro-ecological variations. Thus, three sample districts and six rural Kebeles (2 from each district) were selected for the study. The numbers of sampled households and total populations in the study area were determined by the formula described by Cochran [10]:

$$
\text { No }=\frac{Z^{2} *(p)(q)}{e^{2}}
$$

Where no $=$ required sample size

$\mathrm{Z}^{2}=$ is the abscissa of the normal curve

$\mathrm{e}^{2}=$ is the margin of error (eg. $\pm 0.05 \%$, margin of error for confidence level of $95 \%$ )

$\mathrm{p}=$ is the degree of variability in the attributes being measured refers to the distribution of attributes in the population $\mathrm{q}=1-\mathrm{p}$.

$$
\begin{aligned}
\text { No } & =\frac{\mathrm{Z}^{2} *(\mathrm{p})(\mathrm{q})}{\mathrm{e}^{2}} \\
& =1.96^{2} \times(0.136)(0.864) \div(0.05)^{2} \\
& =3.8416 \times(0.136)(0.864) \div 0.0025 \\
& =180.56 \cong 180
\end{aligned}
$$

\begin{tabular}{|c|c|c|c|c|c|c|}
\hline \multirow{2}{*}{ District } & \multirow{2}{*}{ Agro-ecology } & \multirow{2}{*}{ Kebele } & \multirow{2}{*}{$\begin{array}{l}\text { Household } \\
\text { Inter-viewed }\end{array}$} & \multicolumn{3}{|c|}{ Number selected chicken } \\
\hline & & & & Male & Female & Total selected chicken \\
\hline \multirow{2}{*}{$\begin{array}{l}\text { Faggeta } \\
\text { Lekoma }\end{array}$} & \multirow{3}{*}{ Highland } & Tafoch Danbull & 30 & 36 & 84 & 120 \\
\hline & & Wazi & 30 & 36 & 84 & 120 \\
\hline Sub-total & & & 60 & 72 & 168 & 240 \\
\hline \multirow{2}{*}{ Dangila } & \multirow{3}{*}{ Midland } & Afesa & 30 & 36 & 84 & 120 \\
\hline & & Ligaba & 30 & 36 & 84 & 120 \\
\hline Sub-total & & & 60 & 72 & 168 & 240 \\
\hline \multirow{2}{*}{ Zigom } & \multirow{2}{*}{ Lowland } & Gisayta & 30 & 36 & 84 & 120 \\
\hline & & Kilaji & 30 & 36 & 84 & 120 \\
\hline Sub-total & & & 60 & 72 & 168 & 240 \\
\hline Overall Total & & & 180 & 216 & 504 & 720 \\
\hline
\end{tabular}

Table 1. Sampled house hold and chicken sample in the study area.

\subsection{Data Collection Procedure}

For this study, both primary and secondary data sources were used. In order to collect primary data, the Participatory Rural Appraisal (PRA) involves local communities as active analysts of their own situations where they estimate, quantify, compare and list priorities of resources and constraints of poultry based on their circumstances.

Data generated by the survey includes managemental practice (feeding, housing, watering, health managements and breeding practices), was organizing group discussion. The management practices were assessed through observation the incorporation of recommended scientific husbandry packages applied for each household.

\subsection{Questionnaire Administration and Focus Group Discussion (FGd)}

Focus Group discussion (FGD) was used to undertake discussion with groups composed of key informants were held in each of the selected Kebles by including youngsters, women, model farmers, village leaders, elders, extension workers, and socially respected individuals who are known to have better knowledge on the present and past social and economic status of the area. Based on the information 
generated through Participatory Rural Appraisal (PRA), the questionnaire and record sheets were developed. Aspects of considered trait preference, egg selection, Provision of housing, provision of additional feed, agricultural extension system used, marketing, vaccination practices and use of modern and traditional medication was assessed through questionnaire survey.

\subsection{Participatory Identification of Farmers' Trait Preferences}

Breeding practices, farmers' preferences to traits for breeding stock, farmers' preferences for production traits, selection and culling criteria for indigenous chicken identified in the interviews were presented to each respondent. Traits affecting consumer preferences in purchasing or selling chickens (live weight, plumage color, comb type), "traits" desired by farmers in improving village chickens adaptation (comprising disease and stress tolerance, flightiness/ability to escape predators, scavenging vigour), growth, egg production, plumage color, comb type, reproduction" (broodiness, hatchability of eggs) were presented. Then participants were asked to rank their first, second and third major trait preferences.

\subsection{Descriptive Statistics}

Data collected through questionnaire were described by descriptive statistics using SPSS [11]. Chi-square was employed when required to test the statistical significance of indigenous chicken populations' managemental system. Indexes were calculated to provide ranks for purpose of major constraints, disease type, selection criteria and trait preferences by farmers for breeding of indigenous chickens associated with breeding females and males in the study area. Ranking analyses were used for computing data on farmer's traits preferences, and conformation traits as related to selection of chicken. Indexes were used to calculate the data by using collected from rankings using weighed averages by the following formula employed by Musa et al [12];

$$
\text { Index }=\frac{\sum\left(R_{n} * C_{1}+R_{n-1} * C_{2} \ldots \ldots \ldots \ldots \ldots R_{1}+C_{n}\right. \text { for individual birds }}{\sum\left(R_{n} * C_{1}+R_{n-1} * C_{2} \ldots \ldots \ldots \ldots \ldots \ldots R_{1}+C_{n}\right. \text { for all variable }}
$$

Index was calculated as Index $=$ Sum of $(3 \mathrm{X}$ number of households who ranked first $+2 \mathrm{X}$ number of households who ranked second $+1 \mathrm{X}$ number of households who ranked third) given for an individual reason, criteria or preference divided by the sum of ( $3 \mathrm{X}$ number of households who ranked first $+2 \mathrm{X}$ number of households who ranked second $+1 \mathrm{X}$ number of households who ranked third) for overall reasons, criteria or preferences.

\subsection{The Effective Population Size and Coefficient of Inbreeding}

The effective population size and inbreeding coefficients were calculated on the bases of individual household flock size and combining all the flocks of the community according to Falconer and Mackay [13]. Effective population size for a randomly mated population was

$$
\text { Calculated as: } \mathrm{Ne}=\frac{4(N m)(N f)}{(N m+N f)}
$$

Where: $\mathrm{N}_{\mathrm{e}}=$ effective population size,

$\mathrm{N}_{\mathrm{m}}$ = number of breeding males and

$\mathrm{N}_{\mathrm{f}}=$ number of breeding females.

The rate of inbreeding coefficient $(\Delta \mathrm{F})$ was calculated from $\mathrm{Ne}$ as: $\Delta \mathrm{F}=\frac{1}{2 N e}$

\section{Results and Discussion}

\subsection{Managemental Practice of Local Chickens}

\section{Feed Resources and Feeding Practice}

The major feeds and feeding practices of chickens in the study area as indicated by the respondents were reported in Table 2. The results showed that $85,93.33$ and $78.33 \%$ of the respondents Households in high-land, mid-land, and low-land agro-ecologies, respectively, feed their chicken with some kind of feed in addition to scavenging. The result was in agreement with the report of Halima, H. [14] who reported that $99.3 \%$ of chicken owners in North West Amhara Region provided supplementary feeds to village birds. According to the results of this study, $13.9 \%$ were only scavenging around the backyard. In the current study farmers practiced supplementary feeding system use home grown crops such as $22.6 \%, 24.5 \%, 24.5 \%, 9.0 \%$ and $19.4 \%$, like: wheat, sorghum, maize, barely and mixture with leftovers respectively agro-ecologies.

The type of supplemental feeds varied based on the type of agricultural practice. The frequency of feeding showed that the majority of the respondents $(58.1 \%)$ was Feed chicken three times a day (morning, afternoon and evening), 23.2\% and $18.7 \%$ were feed once and twice (morning and afternoon) respectively. The respondent farmers further reported that chicken were fed on ground $(52.9 \%)$, clay pot $(23.2 \%)$, wooden trough $(16.1 \%)$ and plastic $(7.7 \%)$ containers.

\begin{tabular}{|c|c|c|c|c|c|c|c|c|}
\hline \multirow{3}{*}{ Variables } & \multicolumn{8}{|c|}{ Agro-ecologies } \\
\hline & \multicolumn{2}{|c|}{ Highland } & \multicolumn{2}{|c|}{ Midland } & \multicolumn{2}{|c|}{ Lowland } & \multicolumn{2}{|c|}{ Overall } \\
\hline & $\mathbf{N}$ & $\%$ & $\mathbf{N}$ & $\%$ & $\mathbf{N}$ & $\%$ & $\mathbf{N}$ & $\%$ \\
\hline \multicolumn{9}{|c|}{ (I) Practice of Poultry Feeding } \\
\hline Yes & 51 & 85 & 56 & 93.33 & 48 & 78.33 & 155 & 86.1 \\
\hline No & 9 & 15 & 4 & 6.66 & 12 & 20 & 25 & 13.9 \\
\hline$X^{2}$ value/ $P$ value & & & & & & 4.615 & 0.099 & \\
\hline \multicolumn{9}{|c|}{ (II) Types of Feed Source with Leftover } \\
\hline Wheat & 21 & 41.18 & 9 & 16.12 & 5 & 10.42 & 35 & 22.63 \\
\hline Sorghum & 7 & 13.72 & 9 & 16.12 & 22 & 45.83 & 38 & 24.51 \\
\hline Maize & 8 & 15.68 & 20 & 35.72 & 10 & 20.83 & 38 & 24.52 \\
\hline Barely & 6 & 11.76 & 5 & 8.91 & 3 & 6.25 & 14 & 9.01 \\
\hline Mixture & 9 & 17.66 & 13 & 23.21 & 8 & 16.67 & 30 & 19.40 \\
\hline \multicolumn{5}{|l|}{$\mathrm{X}^{2}$ value/ $\mathrm{P}$ value } & \multicolumn{4}{|c|}{$13.56 / 0.000$} \\
\hline \multicolumn{9}{|c|}{ (III) Frequency of Feeding } \\
\hline
\end{tabular}

Table 2. Feed Resources and Feeding Practice. 


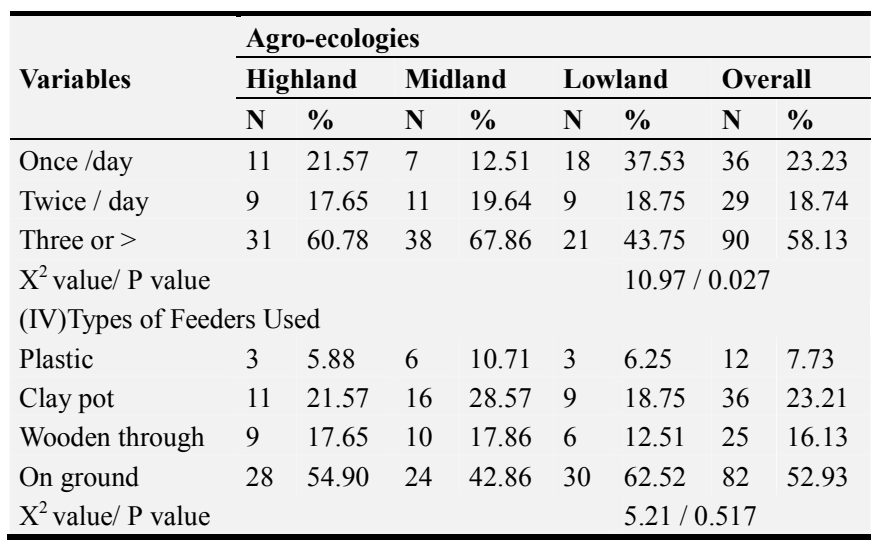

\subsection{Watering Practice}

The results on provision of water to the chicken, based on respondent farmers responses, was presented in Table 3. The results showed that $95 \%$ of respondents provide water their chicken. This result was related with Bekele [15] who reported that $100 \%$ of chicken owners were provided water for their chicken.

The frequencies of watering showed that chicken were provided water ad-libitum (free aces), three times/day, Twice/day and once/day by $85.4,10.5,3.5$ and $0.6 \%$ (overall figures) of respondent farmers in the study area. The study also showed that ad-labium water was provided to chicken in all agro-ecologies, uniformly. Besides in mid-land a small proportion of farmers $(1.79 \%)$ provide once /day water to chicken. The major sources of household water were river, dam (pond), hand pump and spring water in high-land (88.33, 5 and 3.33/3.33\%, respectively); river, hand pump, spring water and dam (pond) in mid-land $(83.33,6.66,6.66$ and $3.33 \%$, respectively); and hand pump, river, dam (pond) and spring water in low-land (46.66, 36.66, 13.33 and 3.33\%, respectively).

In contrast with Shishay Markos [16] showed that well water $(31.7 \%)$, tap water $(29.1 \%)$, river $(27.3 \%)$, tap water and well water $(6.2 \%)$, river and tap water $(4.2 \%)$ as well as river and well water $(1.6 \%)$ sources of water in western Tigray. In this result higher proportion of respondents used river as main sources in high-land $(88.33 \%)$ and mid-land $(83.33 \%)$ due to many source of rivers in Awi zone. However, hand pump was major source of water in low-land (46.66\%) agro-ecology.

In (Table 3) also showed that respondents use watering troughs $90,91.6$ and $96.67 \%$ of respondent farmers in highland, mid-land and low-land agro-ecologies respectively. The watering troughs in high-land and mid-land agro-ecologies were, uniformly, made of clay pot $(35.18,40 \%)$, wooden $(31.48,34.55 \%)$, plastic $(16.67,12.73 \%)$, stone $(9.26,7.27 \%)$ and metallic $(7.40,5.45 \%)$. However, in low-land the watering troughs were made of plastic $(36.2 \%)$, clay pot $(29.3 \%)$, metallic $(15.52 \%)$, wooden $(15.5 \%)$ and stone $(3.45 \%)$. This was in line with the report of Alem, A. T [17] in central Tigray; Mekonnen, G [18] in Southern Ethiopia and Fisseha, M [3] in Bure district.
Table 3. Provision of Water, Watering Frequency, Sources of Water and Watering Trough.

\begin{tabular}{|c|c|c|c|c|c|c|c|c|}
\hline \multirow{3}{*}{ Variables } & \multicolumn{8}{|c|}{ Agro-ecologies } \\
\hline & \multicolumn{2}{|c|}{ High-land } & \multicolumn{2}{|c|}{ Mid-land } & \multicolumn{2}{|c|}{ Low-land } & \multicolumn{2}{|c|}{ Overall } \\
\hline & $\mathbf{N}$ & $\%$ & $\mathbf{N}$ & $\%$ & $\mathbf{N}$ & $\%$ & $\mathbf{N}$ & $\%$ \\
\hline \multicolumn{9}{|c|}{ (I) Provision of Water } \\
\hline Yes & 55 & 91.66 & 56 & 93.33 & 60 & 100 & 171 & 95 \\
\hline No & 5 & 8.33 & 4 & 6.66 & - & - & 9 & 5 \\
\hline$X^{2}$ value/ $P$ value & & & & & & $4.33 / 0$ & 114 & \\
\hline \multicolumn{9}{|c|}{ (II) Frequency of watering } \\
\hline Once /day & - & - & 1 & 1.79 & - & - & 1 & 0.6 \\
\hline Twice / day & 2 & 3.64 & 2 & 3.57 & 2 & 3.33 & 6 & 3.5 \\
\hline Three / day & 6 & 10.90 & 5 & 8.93 & 7 & 11.67 & 18 & 10.5 \\
\hline ad-labium & 47 & 85.46 & 48 & 85.71 & 51 & 85 & 146 & 85.4 \\
\hline $\mathrm{X}^{2}$ value/ $\mathrm{P}$ value & & & & & & $4.68 / 0$ & 322 & \\
\hline \multicolumn{9}{|l|}{ (III) Source of water } \\
\hline River & 53 & 88.33 & 50 & 83.33 & 22 & 36.66 & 125 & 69.4 \\
\hline Hand pump & 2 & 3.33 & 4 & 6.66 & 28 & 46.66 & 34 & 19.0 \\
\hline Dam (pond) & 3 & 5 & 2 & 3.33 & 8 & 13.33 & 13 & 7.2 \\
\hline Spring water & 2 & 3.33 & 4 & 6.66 & 2 & 3.33 & 8 & 4.4 \\
\hline $\mathrm{X}^{2}$ value/ $\mathrm{P}$ value & & & & & & $6.74 / 0$. & 00 & \\
\hline \multicolumn{9}{|c|}{ (IV) Availability of watering through } \\
\hline Yes & 54 & 90 & 55 & 91.6 & 58 & 96.67 & 167 & 92.78 \\
\hline No & 6 & 10 & 5 & 8.33 & 2 & 3.33 & 13 & 7.22 \\
\hline $\mathrm{X}^{2}$ value/ $\mathrm{P}$ value & & & & & & $2.236 /$ & .327 & \\
\hline \multicolumn{9}{|c|}{ (V) Types of watering through } \\
\hline Clay pot & 19 & 35.18 & 22 & 40 & 17 & 29.3 & 58 & 35.08 \\
\hline Plastic & 9 & 16.67 & 7 & 12.73 & 21 & 36.2 & 37 & 22.16 \\
\hline Wooden & 17 & 31.48 & 19 & 34.55 & 9 & 15.5 & 43 & 26.94 \\
\hline Stone & 5 & 9.26 & 4 & 7.27 & 2 & 3.45 & 11 & 6.58 \\
\hline Metallic & 4 & 7.40 & 3 & 5.45 & 9 & 15.52 & 16 & 9.58 \\
\hline$X^{2}$ value/ $P$ value & & & & & & 24.694 & 0.002 & \\
\hline
\end{tabular}

\subsection{Housing System}

The result on poultry housing is presented in Table 4 . The study showed that poultry housing was provided by $96.66 \%$, 93.33 and 85 of respondents in high-land, mid-land and lowland, agro-ecologies respectively. The possible reason might be that housing was essential to chickens as it protects them against predators, theft, weather conditions like: (rain, sun, wind...) and Provide nesting place (egg laying place of laying hens). The present study showed that five type of housing were provided and these were separate house, perch in kitchen, perch on veranda, perch inside main house and handmade basket but proportion of respondents using these types of housing was different in the three agro-ecologies. In high-land agro-ecologies the order of housing was, Handmade Basket, Separate house, Perch inside Main House, Perch on Veranda, and Perch in Kitchen (46.55, 29.3, 13.79, 6.9 and $3.45 \%$, respectively).

Similarly the order of housing in mid-land was perch inside main House, separate house, perch in kitchen, handmade basket and perch on veranda $(33.93,25,19.64$, 16.07 and $5.36 \%$, respectively) and in low-land the order of housing was separate house, perch on veranda, perch in kitchen, perch inside main house and handmade basket (37.25, 25.49, 21.57, 9.8 and $5.88 \%$, respectively). The overall results showed that only $30.3 \%$ of respondents 
provided separate house for chicken. The possible reason for low proportion of farmers providing separate house for chicken might be lack of awareness of advantages of separate housing of poultry, lack of awareness of risks involved in keeping chicks in family house, is keep of theft and predator attack.

This result was much lower than Hassen, H, [19], Bogale K, [20], Shishay Markos [16], Mearg, F [21] those who were reported that $50.77 \%, 59.7 \%, 59.5 \%, 65.7 \%$ and $76.7 \%$, of the total respondents constructed separate chicken houses in Southwest and central zone of Tigray, Lemo District Hadiya Zone, North west of Ethiopia and Fogera district, respectively. However, this result was much higher than from a report of Alem, A. [7] in which only $3.6 \%$ of respondents in Gomma district constructed separate chicken house.

Table 4. Poultry Housing System of the Study Areas.

\begin{tabular}{|c|c|c|c|c|c|c|c|c|}
\hline \multirow{3}{*}{ Variables } & \multicolumn{8}{|c|}{ Agro-ecologies } \\
\hline & \multicolumn{2}{|c|}{ Highland } & \multicolumn{2}{|c|}{ Midland } & \multicolumn{2}{|c|}{ Lowland } & \multicolumn{2}{|c|}{ Overall } \\
\hline & $\mathbf{N}$ & $\%$ & $\mathbf{N}$ & $\%$ & $\mathbf{N}$ & $\%$ & $\mathbf{N}$ & $\%$ \\
\hline \multicolumn{9}{|c|}{ (I) Availability of Poultry Housing } \\
\hline Yes & 58 & 96.66 & 56 & 93.33 & 51 & 85 & 165 & 91.7 \\
\hline No & 2 & 3.33 & 4 & 6.66 & 9 & 15 & 15 & 8.3 \\
\hline $\mathrm{X}^{2}$ value/ $\mathrm{P}$ value & & & & & & $5.673 /$ & 0.059 & \\
\hline \multicolumn{9}{|c|}{ (II) Types of Housing } \\
\hline Separate House & 17 & 29.3 & 14 & 25 & 19 & 37.25 & 50 & 30.3 \\
\hline Perch in Kitchen & 2 & 3.45 & 11 & 19.64 & 11 & 21.57 & 24 & 14.4 \\
\hline Perch on Varenda & 4 & 6.92 & 3 & 5.36 & 13 & 25.49 & 20 & 12.1 \\
\hline Perch inside Main & 8 & 13.79 & 19 & 33.93 & 5 & 9.81 & 32 & 19.4 \\
\hline
\end{tabular}

\begin{tabular}{|c|c|c|c|c|c|c|c|c|}
\hline \multirow{3}{*}{ Variables } & \multicolumn{8}{|c|}{ Agro-ecologies } \\
\hline & \multicolumn{2}{|c|}{ Highland } & \multicolumn{2}{|c|}{ Midland } & \multicolumn{2}{|c|}{ Lowland } & \multicolumn{2}{|c|}{ Overall } \\
\hline & $\mathbf{N}$ & $\%$ & $\mathbf{N}$ & $\%$ & $\mathbf{N}$ & $\%$ & $\mathbf{N}$ & $\%$ \\
\hline \multicolumn{9}{|l|}{ House } \\
\hline Handmade Basket & 27 & 46.55 & 9 & 16.07 & 3 & 5.88 & 39 & 23.6 \\
\hline $\mathrm{X}^{2}$ value/ $\mathrm{P}$ value & & & & & & $8.210 /$ & 0.00 & \\
\hline \multicolumn{9}{|c|}{ (III) Frequency of Cleaning } \\
\hline Daily & 25 & 41.66 & 23 & 38.33 & 16 & 26.66 & 64 & 35.6 \\
\hline In 2 Days & 7 & 11.66 & 5 & 8.33 & 11 & 18.33 & 23 & 12.8 \\
\hline In 3 Days & 3 & 5 & 8 & 13.33 & - & - & 11 & 6.1 \\
\hline Weekly & 18 & 30 & 20 & 33.33 & 27 & 45 & 65 & 35.1 \\
\hline Monthly & 7 & 11.66 & 4 & 6.66 & 6 & 10 & 17 & 9.4 \\
\hline $\mathrm{X}^{2}$ value/ $\mathrm{P}$ value & & & & & & 16.323 & 0.0 & \\
\hline
\end{tabular}

\subsection{Poultry Health Management}

\section{(A) Ranking of Diseases}

The ranking of diseases by respondents were presented in Table 5. Perusal of results showed that Newcastle (locally called as "Wotetie"), parasitic infestation and diseases of unknown origin were ranked as number one, two and three with index values of $0.422,0.306,0.272$ in high-land and $0.410,0.295$ and 0.295 in low-land areas.

However, in mid-land though Newcastle disease was ranked as number one (with index value of 0.436) but number two and three ranks were unknown origin (with index value of 0.292 ) and parasitic infestation (with index value of 0.272). Hassen, H [19], Addisu H. [4] also reported that the major cause of death in local chicken is seasonal outbreak of Newcastle (NCD).

Table 5. Ranking of Diseases by respondent HH.

\begin{tabular}{|c|c|c|c|c|c|c|c|c|c|c|c|c|}
\hline \multirow{3}{*}{ Diseases } & \multicolumn{12}{|c|}{ Agro ecology } \\
\hline & \multicolumn{4}{|c|}{ High land } & \multicolumn{4}{|c|}{ Mid land } & \multicolumn{4}{|c|}{ Low land } \\
\hline & R1 & $\mathbf{R 2}$ & R3 & Index & R1 & $\mathbf{R 2}$ & R3 & Index & R1 & $\mathbf{R 2}$ & R3 & Index \\
\hline New castle Disease & 42 & 8 & 10 & 0.422 & 35 & 22 & 3 & 0.436 & 45 & 10 & 5 & 0.410 \\
\hline Parasitic Infestation & 10 & 15 & 35 & 0.306 & 10 & 30 & 20 & 0.272 & 10 & 35 & 15 & 0.295 \\
\hline Unknown & 5 & 36 & 15 & 0.272 & 15 & 8 & 37 & 0.292 & 15 & 15 & 40 & 0.295 \\
\hline
\end{tabular}

\section{(B) Occurrence and Treatment of Diseases:}

The results on occurrence and treatment of diseases were presented in Table 6. In the present study 96.66, 100 and $96.66 \%$ of respondents reported that diseases were occurring in high-land, mid-land and low-land, agro-ecologies, respectively. Regarding, to measures taken for sick chickens in the study area sick chicken in high-land, mid-land and low-land agro-ecologies, about $31.03,30$ and $24.14 \%$ of the respondent treat by themselves, $18.97,13.33$ and $24.14 \%$ of the respondents treat by Slaughter for home consumption, $27.59,36.66$ and $17.24 \%$ of the respondents treat by Selling to market, $17.24,16.66$ and $20.68 \%$ of the respondent treat by no-action and but only $5.17,3.33$ and $13.79 \%$ respondent was tack to veterinary for treatment of sick chicken in 3 agroecologies respectively.

This result was similarly, Abdelqader, A [22] reported that only $5 \%$ of the farmers accessed veterinary extension service. The study showed that $96.66,91.66$ and $98.33 \%$ of respondents reported that vaccination was not available for control of some important poultry diseases. This finding was lower than that reported by Melaku, T [23] who stated that $87,78 \%$ respondents did not vaccinated their birds in Wogdi, Borena and Legambo districts. There could be many reasons reported by respondents for non-vaccination of chicken and these were: (i) Lack of attention (31.03, 49.09, and 50.85\%); (ii) No access that requires more than their costs $(32.77$, 10.91 and 20.34\%); (iii) Lack of awareness (25.86, 34.55 and11.86\%); and (iv) No information about vaccination availability $(10.34,5.45$ and $16.95 \%)$ in high-land, mid-land and low-land agro-ecologies, respectively. Similarly, Fisseha, M., [3] also reported that lack of awareness about the presence of vaccine $(71.4 \%)$, lack of attention to village birds $(13.6 \%)$ and low availability of vaccines $(15 \%)$ were the major reasons for lack of vaccination against diseases in Bure district, North West Ethiopia. 
Table 6. Disease Parasite and Vaccination Availability in the Study Area.

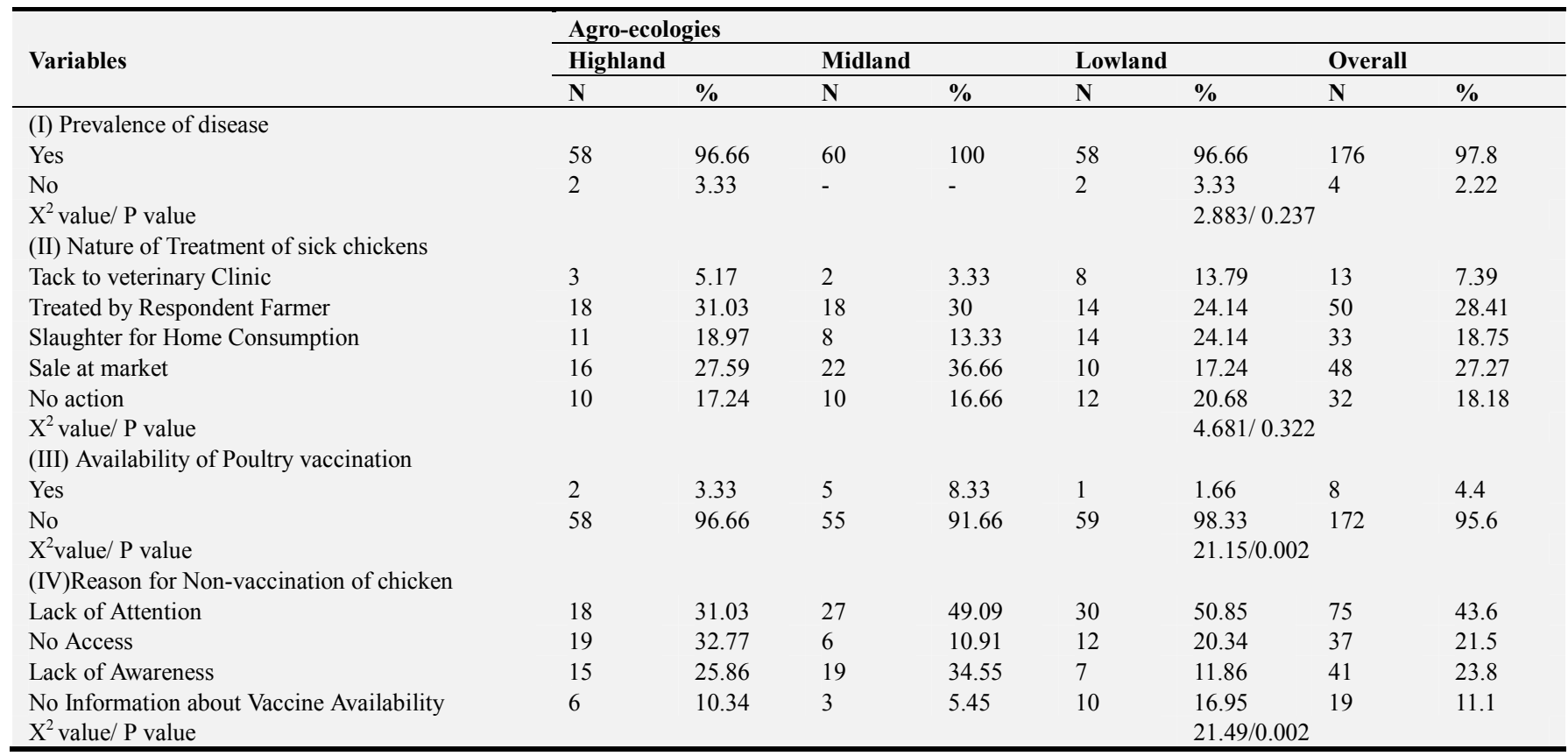

\subsection{Source of Disease, Parasite and Control Measures}

The sources of diseases, Parasite and control measures, in the study areas was presented in Table 7. According to respondents in the study area, the incoming flock (either neighbor's flock or immigrants) was the major source of chicken infection (46.66, 60 and 53.33\%) in all high-land, mid-land and low-land, respectively.

The present study showed that respondent farmers have experience about prevalence of diseases as indicated (65, 70 and $55 \%$ in high-land, mid-land and low-land, respectively). The respondent farmers further reported that indigenous practices were carried to treat sick birds and three types of indigenous practices were giving juice of leaves, bleeding under wing and Giving Juice of Leaf of Chikugni whereas a proportion of farmers took No prevention for treatment of sick birds.

The overall results showed that 30.70, 28.95, 20.17 and $20.17 \%$ of respondents treated sick birds by Bleeding under wing, No prevention, giving juice of leaves and Giving Juice of Leaf of Chikugni, respectively. Similarly, Fisseha, M., [3], Emebet, M., 24, Addisu H. [4,] also reported that the major cause of death in local chicken in North West Ethiopia Bure district in South West and South Part of Ethiopia and North Wollo were seasonal outbreak of diseases, specifically Newcastle Disease.

The majority of respondents $(85,78.33$ and $71.66 \%)$ knew about parasitic infestation in high-land, mid-land and lowland, agro-ecologies (AEGs), respectively. The indigenous practices, via: Smoking, Changing place, No intervention and spring medicine, were used to control parasitic infestation in the study areas. The overall results showed that 55.32, 17, 14.89 and $12.76 \%$ of respondents practiced Smoking, Changing place, spring medicine and No intervention, respectively, for controlling parasitic infestation.
Table 7. Source of Disease, Parasite and Control Measures.

\begin{tabular}{|c|c|c|c|c|c|c|c|c|}
\hline \multirow{3}{*}{ Variables } & \multicolumn{8}{|c|}{ Agro-ecologies } \\
\hline & \multicolumn{2}{|c|}{ Highland } & \multicolumn{2}{|c|}{ Midland } & \multicolumn{2}{|c|}{ Lowland } & \multicolumn{2}{|c|}{ Overall } \\
\hline & $\mathbf{N}$ & $\%$ & $\mathbf{N}$ & $\%$ & $\mathbf{N}$ & $\%$ & $\mathbf{N}$ & $\%$ \\
\hline \multicolumn{9}{|c|}{ (I) Source of disease } \\
\hline Incoming flock & 28 & 46.66 & 36 & 60 & 32 & 53.33 & 96 & 53.33 \\
\hline Own flock & 15 & 25 & 13 & 21.66 & 11 & 18.33 & 39 & 21.67 \\
\hline Unknown & 17 & 28.33 & 11 & 18.33 & 17 & 28.33 & 45 & 25 \\
\hline \multicolumn{8}{|c|}{ (II) Experience of Farmers about Prevalence of Disease } & \\
\hline Yes & 39 & 65 & 42 & 70 & 33 & 55 & 114 & 63.3 \\
\hline No & 21 & 35 & 18 & 30 & 27 & 45 & 66 & 36.7 \\
\hline $\begin{array}{l}\mathrm{X}^{2} \text { value/ } \mathrm{P} \text { value } \\
\text { (III) Indigenous } \mathrm{P}\end{array}$ & actic & s about & Prev & ating D & sease & $3.014 /$ & 0.222 & \\
\hline $\begin{array}{l}\text { Giving juice of } \\
\text { leaves }\end{array}$ & 7 & 17.95 & 8 & 19.05 & 8 & 24.24 & 23 & 20.17 \\
\hline $\begin{array}{l}\text { Bleeding under } \\
\text { wing }\end{array}$ & 12 & 30.76 & 13 & 30.95 & 10 & 30.30 & 35 & 30.70 \\
\hline $\begin{array}{l}\text { Giving Juice of } \\
\text { Leaf of Chikugni }\end{array}$ & 13 & 33.33 & 10 & 23.80 & - & - & 23 & 20.17 \\
\hline $\begin{array}{l}\text { No prevention } \\
\mathrm{X}^{2} \text { value/ } \mathrm{P} \text { value }\end{array}$ & 7 & 17.95 & 11 & 26.19 & 15 & $\begin{array}{l}45.45 \\
4.13 / 0 .\end{array}$ & $\begin{array}{r}33 \\
000\end{array}$ & 28.95 \\
\hline \multicolumn{9}{|c|}{ (IV) Farmer experience about Parasitic Infestation among Chicken } \\
\hline Yes & 51 & 85 & 47 & 78.33 & 43 & 71.66 & 141 & 78.3 \\
\hline No & 9 & 15 & 13 & 21.66 & 17 & 28.33 & 39 & 21.7 \\
\hline $\mathrm{X}^{2}$ value/ $\mathrm{P}$ value & & & & & & $3.142 /($ & 208 & \\
\hline \multicolumn{9}{|c|}{ (V) Indigenous knowledge about prevention of external parasite } \\
\hline Smoking & 36 & 70.58 & 31 & 65.96 & 11 & 25.58 & 78 & 55.32 \\
\hline Changing place & 7 & 13.72 & 7 & 14.89 & 10 & 21.66 & 24 & 17 \\
\hline No intervention & 5 & 9.8 & 3 & 6.38 & 10 & 23.26 & 18 & 12.76 \\
\hline Spring medicine & 3 & 5.88 & 6 & 12.76 & 12 & 27.9 & 21 & 14.89 \\
\hline $\mathrm{X}^{2}$ value/ $\mathrm{P}$ value & & & & & & $5.69 / 0$ & 000 & \\
\hline
\end{tabular}

\subsection{Occurrence of Predator}

The occurrence of predators in the study areas was presented in Table 8; the majority proportion $(98.33,96.66$ and $100 \%$ in high-land, mid-land and low-land, respectively) respondents reported that predators were occurring in the 
study areas. This result was in line with report of Halima, H., [14] that predation was one of the major constraints in village chicken production in northwest Ethiopia. The most common predators mentioned by respondents were Vulture, wild Cat, Dog, Snake, Bee bitt and "sulsuly/fotte/" (locally available predators of wild animal in this area) in Table 13 but the attack of predator was vary from agro-ecology to agroecology. Vultures were common in all area that attack during the dry season December to June but June to October is covered scavenging areas by crops.

Snakes were common predators in low-land agro-ecology whereas Cat of wild and Dogs were in all agro-ecologies. Local name sulsuly/fotte were wild animal predators common in all agro-ecologies that attacks poultry in rainy seasons for the standing crops in the field were providing camouflage to these predators and poultry were becoming easy target due to this. Bee-bitt was more common in highland and mid-land areas it might be bees present in backyard in both agro-ecology but in lowland bees live mostly on trees responding by the owners.

This result was in line with report of Halima, H., [14] that predation is one of the major constraints in village chicken production in northwest Ethiopia. The average mean types of predators were $28.81 \%, 53.17 \%$ and $33.33 \%$ Vulture, $16.95 \%, 10.34 \%$ and $16.66 \%$ Cat, $16.95 \%, 6.9 \%$ and $11.66 \%$ Dog, 0,0 and $20 \%$ Snake, $15.26 \%, 10.34 \%$ and 0 Bee bitt and $22.03 \%, 17.24 \%$ and $20 \%$ Sulsuly/fotte/ of respondents were respond in high-land, mid-land and low-land areas respectively. This result was in agreement with Hunduma, D., [25] reported that predators such as birds of prey (locally known as "Culullee") (34\%), cats and dogs (16.3\%) and wild animals $(15 \%)$ were identified as the major causes of village poultry in rift valley of Oromia, Ethiopia.

Table 8. Availability and Types of Predator in the Study Area.

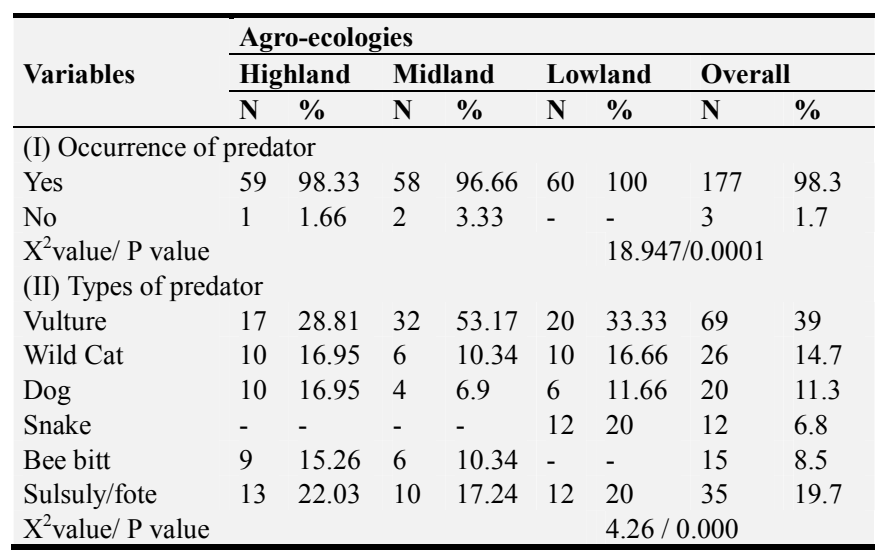

\section{Marketing Practice of Local Chicken and Eggs}

The results of marketing practice and methods of transportation were presented in Table 9. The results showed that all respondent farmers participated in sale of chicken in all agro-ecologies (AEGs). The results, based on respondent survey, showed that sale of chicks was conducted by women and their proportion was more than $70 \%$ in all agro-ecologies (AEGs). The children were next in order $(>10 \%$ but $<20 \%)$ involved in selling of chicken in all agro-ecologies.

The main markets preferred by farmers for sale of chicken were $55 \%, 60 \%$ and $46.66 \%$ of the nearest urban market followed by $40 \%, 26.66 \%$ and $28.33 \%$ district market and $5 \%$, $13.33 \%$ and $25 \%$ Neighbor-hood market in high-land, midland and low-land agro-ecologies respectively. Sale of chicken is an important source of income in all agro-ecologies. Regarding means of transportation of chicken to markets, the majority $53.33 \%$ in high-land, $(76.66 \%$ in mid-land, and $65 \%$ in low-land) of the farmers transported on foot carrying their chicken by hand, hanging upside down on a piece of stick, $11.66 \%$ in high-land, $6.66 \%$ in mid-land and $21.66 \%$ in lowland by car $30 \%$ in high-land, $13.33 \%$ in mid-land and $5 \%$ in low-land transported In basket and 5\% in high-land, 3.33\% in mid-land and $8.33 \%$ in low-land were transported by embracing one or two hens only were means of transportation. This result was similar with Mearg, F. E [21] transportation of chicken to markets, the majority $(74.5 \%$ in midland, $56.7 \%$ in highland) of the farmers transported on foot carrying their chicken. The respondent farmers reported that more than $75 \%$ of respondent practice egg selling. The proportion of respondents practicing egg selling in Highland, Midland and Lowland were $85.00,78.33$ and $95.00 \%$ in present study. The result showed that in high-land, mid-land and low-land the eggs were stored: $52.94,44.68$ and $29.82 \%$ in grain, 27.45 , 36.17 and $36.84 \%$ in straw and $19.61,19.15$ and $33.33 \%$ in plastic respectively. In addition to its use in storage of eggs until incubation and or marketing, the grain/straw also used to protect eggs from rupture during transportation. This result was in line with finding of Abdelqader, A [22] reported that farmers sold chickens and eggs to their neighbors and in the main markets to other farmers and middle men.

Table 9. Marketing Practice and Methods of Transportation.

\begin{tabular}{|c|c|c|c|c|c|c|c|c|}
\hline \multirow{3}{*}{ Variables } & \multicolumn{8}{|c|}{ Agro-ecologies } \\
\hline & \multicolumn{2}{|c|}{ Highland } & \multicolumn{2}{|c|}{ Midland } & \multicolumn{2}{|c|}{ Lowland } & \multicolumn{2}{|c|}{ Overall } \\
\hline & $\mathbf{N}$ & $\%$ & $\mathbf{N}$ & $\%$ & $\mathbf{N}$ & $\%$ & $\mathbf{N}$ & $\%$ \\
\hline \multicolumn{9}{|c|}{ (I) Prevalence of Chicken Sale } \\
\hline Yes & 60 & 100 & 60 & 100 & 60 & 100 & 60 & 100 \\
\hline \multicolumn{9}{|c|}{ (II) Role of Family Members in Selling } \\
\hline Male & 4 & 6.67 & 6 & 10 & 6 & 10 & 16 & 8.89 \\
\hline Female & 49 & 81.67 & 45 & 75 & 43 & 71.66 & 137 & 76.11 \\
\hline Children & 7 & 11.66 & 9 & 15 & 11 & 18.34 & 27 & 15 \\
\hline \multicolumn{9}{|c|}{$\begin{array}{l}\mathrm{X}^{2} \text { value/ } \mathrm{P} \text { value } 2.56 / 0.617 \\
\text { (III) Marketing place of chicken }\end{array}$} \\
\hline district market & 24 & 40 & 16 & 26.66 & 17 & 28.33 & 57 & 31.7 \\
\hline Neighbor-hood & 3 & 5 & 8 & 13.33 & 15 & 25 & 26 & 14.4 \\
\hline Nearest market & 33 & 55 & 36 & 60 & 28 & 46.66 & 97 & 53.9 \\
\hline $\mathrm{X}^{2}$ value/ $\mathrm{P}$ value & & & & & & 11.397 & $/ 0.022$ & \\
\hline \multicolumn{9}{|c|}{ (IV) Methods of transportation chickens } \\
\hline Hanging by hand & 32 & 53.33 & 46 & 76.66 & 39 & 65 & 117 & 65 \\
\hline By car & 7 & 11.66 & 4 & 6.66 & 13 & 21.66 & 24 & 13.3 \\
\hline In basket & 18 & 30 & 8 & 13.33 & 3 & 5 & 29 & 16.1 \\
\hline Embracing & 3 & 5 & 2 & 3.33 & 5 & 8.33 & 10 & 5.6 \\
\hline \multicolumn{9}{|c|}{$\begin{array}{l}X^{2} \text { value/ P value } 21.232 / 0.002 \\
\text { (V) Practice of Egg Selling }\end{array}$} \\
\hline Yes & 51 & 85 & 47 & 78.33 & 57 & 95 & 155 & 86.1 \\
\hline No & 9 & 15 & 13 & 21.66 & 3 & 5 & 25 & 13.9 \\
\hline $\begin{array}{l}X^{2} \text { value/ P value } \\
\text { (VI) Methods of } t\end{array}$ & ransp & ortation & egg & $7.061 /$ & 0.029 & & & \\
\hline Eggs in grain & $27^{1}$ & 52.94 & 21 & 44.68 & 17 & 29.82 & 65 & 41.94 \\
\hline
\end{tabular}




\begin{tabular}{|c|c|c|c|c|c|c|c|c|}
\hline \multirow{3}{*}{ Variables } & \multicolumn{8}{|c|}{ Agro-ecologies } \\
\hline & \multicolumn{2}{|c|}{ Highland } & \multicolumn{2}{|c|}{ Midland } & \multicolumn{2}{|c|}{ Lowland } & \multicolumn{2}{|c|}{ Overall } \\
\hline & $\mathbf{N}$ & $\%$ & $\mathbf{N}$ & $\%$ & $\mathbf{N}$ & $\%$ & $\mathbf{N}$ & $\%$ \\
\hline Eggs in straw & 14 & 27.45 & 17 & 36.17 & 21 & 36.84 & 52 & 33.55 \\
\hline Eggs in plastic & 10 & 19.61 & 9 & 19.15 & 19 & 33.33 & 38 & 24.51 \\
\hline $\mathrm{X}^{2}$ value/ $\mathrm{P}$ value & & & & & & 14.167 & $7 / 0.00$ & \\
\hline
\end{tabular}

\subsection{The Prices of Chicken and Price Determinant Factors}

The results on sale prices of chicks and eggs and factors determining these prices were presented in Tables 10 and 11 . The interview of respondent farmers showed that the sale prices were113.28 $\pm 4.86,113.48 \pm 5.48$ and $97.9 \pm 4.28$ average price of cock, $98.85 \pm 3.70,93.97 \pm 3.55$ and $91.63 \pm 3.99$ average price of hen and $2.80 \pm 0.03$, $3.07 \pm 0.37$ and $2.48 \pm 0.03$ average price of egg in high-land, mid-land and low-land agro-ecologies respectively in Table 10. The average price of eggs showed significant differences among the three agro-ecologies and Highland-Midland agroecology differed significantly in the average price of eggs.

The prices obtained in this finding were significantly higher as compared with Addisu H [4] who reported that 71 \pm 2.14 for cock, $53.56 \pm 2.24$ for hens and $1.70 \pm 0.056$ for eggs birr per matured cocks, hens and eggs, respectively, in north Gonder zone Amhara region.

Table 10. The Prices of Chicken and Price Determinant.

\begin{tabular}{llllll}
\hline \multirow{3}{*}{ Variable } & Agro ecology & & & & P \\
\cline { 2 - 6 } & High-land & Mid-land & Low-land & Overall & Value \\
\cline { 2 - 6 } & \multicolumn{1}{c}{ Mean \pm SE } & Mean \pm SE & Mean \pm SE & Mean \pm SE & P value \\
\hline (I) Sale price of Chicks and Eggs: & & & & \\
Average price of cock & $113.28 \pm 4.86$ & $113.48 \pm 5.48$ & $97.9 \pm 4.28$ & $108.23 \pm 2.87$ & 0.134 \\
Average price of hen & $98.85 \pm 3.70$ & $93.97 \pm 3.55$ & $91.63 \pm 3.99$ & $94.82 \pm 2.16$ & 0.134 \\
Average price of egg & $2.80^{\mathrm{ab}} \pm 0.03$ & $3.07^{\mathrm{a}} \pm 0.37$ & $2.48^{\mathrm{b}} \pm 0.03$ & $2.78 \pm 0.126$ & 0.000 \\
\hline
\end{tabular}

Regarding to price determinant factors the result of the study in Table 11 indicated that almost all the respondents' reported that the price of live chickens varies based on different determinant factors. According to the result of overall 'interview was plumage color and body weight $33.3 \%$, Body weight $27.2 \%$, plumage color $14.4 \%$, comb type $13.4 \%$, sex of chicken $7.8 \%$, breed of chicken $3.9 \%$, were the major factors that cause variation in the price of live chickens in high-land, mid-land and low-land agro-ecologies respectively.

This result was in line with finding of Addisu H [4] who reported that the prices of live chickens were determined based on body weight (41.83\%), combination of comb type and plumage color (32.35\%) and plumage color $(25.82 \%)$ in buying and selling marketing system in North Wollo zone of Ethiopia. And Markos, S. [26] who reported that plumage color, body weight, comb type, shank color, smoothness of shank, sex, length of legs, head shape and market site were the major factors that cause variation in the price of live chickens in western zone of Tigray. The current finding was also in agreement with report of Fisseha, M [3].

Table 11. The Prices of Chicken and Price Determinant.

\begin{tabular}{|c|c|c|c|c|c|c|c|c|}
\hline Plumage colour & 11 & 18.33 & 9 & 15 & 6 & 10 & 26 & 14.4 \\
\hline Comb type & 5 & 8.33 & 7 & 11.66 & 12 & 20 & 24 & 13.4 \\
\hline Sex of chicken & 2 & 3.33 & 4 & 6.66 & 8 & 13.33 & 14 & 7.8 \\
\hline Breed of chicken & 5 & 8.33 & 2 & 3.33 & - & - & 7 & 3.9 \\
\hline Body weight & 16 & 26.66 & 18 & 30 & 15 & 25 & 49 & 27.2 \\
\hline Weight and plumage & 21 & 35 & 20 & 33.33 & 19 & 31.66 & 60 & 33.3 \\
\hline $\mathrm{X}^{2}$ value/ & & $P$ value & & $14.526 /$ & & 0.15 & & \\
\hline
\end{tabular}

\subsection{Management of Egg and Incubation Practice}

The results on management of egg and incubation practice of indigenous chicken, based on respondent survey, were presented in Table 12. The availability of egg management practices are very important for incubation and quality egg transformed to consumers. The results Table 12 showed that more than $70 \%$ of respondent farmers were aware of proper management of eggs in the three agro-ecologies $(80,90$ and $70 \%$ in Highland, Midland and Lowland agro-ecologies, respectively). In this study $27.08 \%, 35.19 \%$ and $26.19 \%$ of the farmers collected eggs daily; $37.5 \%, 31.48 \%$ and $23.81 \%$ collected every two day; $25 \%, 18.52 \%$ and $21.43 \%$ collected every three day; and $10.42 \%, 14.81 \%$ and $28.57 \%$ did not collect eggs until incubation in high-land, mid-land and lowland agro-ecologies, respectively.

The overall mean proportion of respondents reported that
$45.6 \%$ respondents stored eggs in mixed with grains; $27.2 \%$ stored in plastic container; $25 \%$ stored in clay pot mixed with left-over of fruits; and $2.2 \%$ stored on ground with sand. It appeared that storing of eggs with grain was a relatively more common practice in the study area.

Table 12. Management of Egg, Frequency of Egg Collection and Storage of Egg in the Study Area.

\begin{tabular}{|c|c|c|c|c|c|c|c|c|}
\hline \multirow{3}{*}{ Variable } & \multicolumn{8}{|c|}{ Agro-ecology } \\
\hline & \multicolumn{2}{|c|}{ Highland } & \multicolumn{2}{|c|}{ Midland } & \multicolumn{2}{|c|}{ Lowland } & \multicolumn{2}{|c|}{ Overall } \\
\hline & $\mathbf{N}$ & $\%$ & $\mathbf{N}$ & $\%$ & $\mathbf{N}$ & $\%$ & $\mathbf{N}$ & $\%$ \\
\hline \multicolumn{9}{|c|}{ (I) Availability of egg management } \\
\hline Yes & 48 & 80 & 54 & 90 & 42 & 70 & 144 & 80 \\
\hline No & 12 & 20 & 6 & 10 & 18 & 30 & 36 & 20 \\
\hline \multicolumn{8}{|c|}{ (II) Frequency of egg collection } & \\
\hline Every day & 13 & 27.08 & 19 & 35.19 & 11 & 26.19 & 52 & 28.9 \\
\hline Every2da & 18 & 37.5 & 17 & 31.48 & 10 & 23.81 & 57 & 31.7 \\
\hline Every3da & 12 & 25 & 10 & 18.52 & 9 & 21.43 & 44 & 24.4 \\
\hline
\end{tabular}




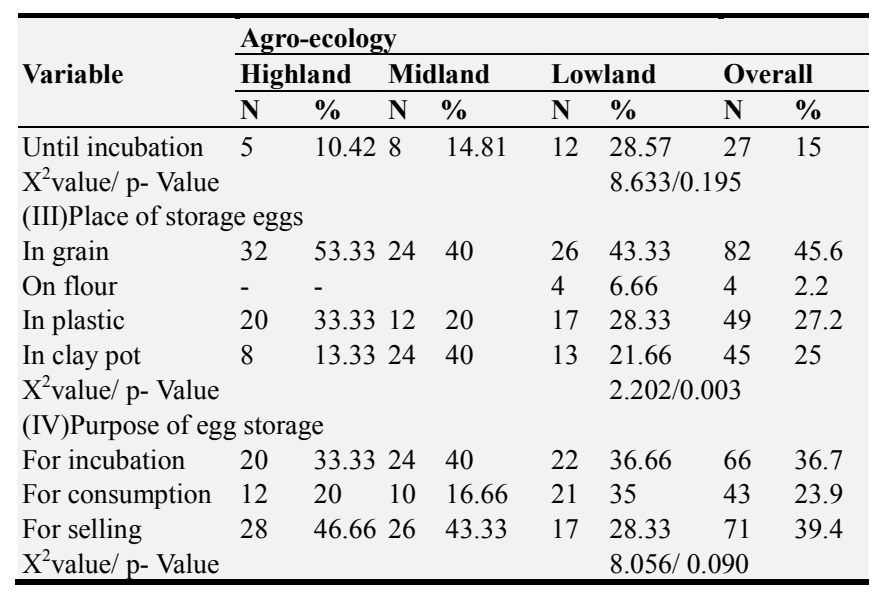

The results showed in Table 13 that eggs were stored, based on respondents survey, for sale $(46.66,43.33,28.33 \%$ in Highland, Midland and Lowland agro-ecologies, respectively); for incubation $(33.33,40.00,36.66 \%$ in Highland, Midland and Lowland agro-ecologies respectively); and for consumption $(20.00,16.66,35.00 \%$ in Highland, Midland and Lowland agro-ecologies, respectively) in the present study. The overall durations of egg storage showed that eggs were stored until incubation ( $41.1 \%$ of respondents), less than one week $(20.6 \%$ of respondents), two weeks $(19.4 \%$ of respondents) and 3 weeks (18.9\% of respondents) in the present study. The majority of respondents stored eggs until incubation $(43.33,53.33$, and $26.66 \%$ in Highland, Midland and Lowland agro-ecologies, respectively).

The results Table 13 also indicated that more than $70 \%$ of respondent farmers selected eggs before incubation and proportion of these respondents for Highland, Midland and Lowland agro-ecologies were $73.33,80.00$ and $70.00 \%$, respectively. The results on criteria of selection of eggs revealed that absence of Cracks and shape of eggs were number one and two criteria in all three agro-ecologies as indicated by proportion of respondent farmers $(56.82,62.5$, $59.52 \%$ respondents for absence of cracks; and 25, 18.75, $21.43 \%$ respondents for shape of egg in Highland, Midland and Lowland agro-ecologies, respectively). The study of Meseret, M., [7] also indicated that farmers select eggs for incubation based on certain criteria but the criteria observed in this study (body size, sufficient plumage cover and previous hatching history of the hen) were not same as observed in current study. This indicated that there was variation in the selection criteria of eggs for incubation from area to area depending upon perception of farmers in each area.

Perusal of Table 13 indicated that natural incubation was the most commonly used method by majority of respondents (96.66, 93.3, and 100\% in Highland, Midland and Lowland agro-ecologies, respectively) for incubating and rearing chicks in the present study. The hay box brooder was used by a very small proportion of respondents in Highland $(3.33 \%$ of respondents) and Midland (6.66\% of respondents) agroecology only. This needs to be addressed, in view of the advantages of hay box brooder, by extension agencies. Perusal of table 13 showed that different bedding material was used during incubation in the study area. The overall proportion of farmers using Clay pot with straw, Mud container with straw, Under holes with sand, Plastic material and Wooden made with straw were 31.03, 25.86, 22.98, 10.34 and $9.77 \%$, respectively, in the present study.

Table 13. Incubation Practices in Study Areas.

\begin{tabular}{|c|c|c|c|c|c|c|c|c|}
\hline \multirow{3}{*}{ Variable } & \multicolumn{6}{|c|}{ Agro ecology } & \multirow{2}{*}{\multicolumn{2}{|c|}{ Overall }} \\
\hline & \multicolumn{2}{|c|}{ Highland } & \multicolumn{2}{|c|}{ Midland } & \multicolumn{2}{|c|}{ Lowland } & & \\
\hline & $\overline{\mathbf{N}}$ & $\%$ & $\mathbf{N}$ & $\%$ & $\mathbf{N}$ & $\%$ & $\mathbf{N}$ & $\%$ \\
\hline \multicolumn{9}{|l|}{ (I) Duration of eggs storage } \\
\hline One week & 12 & 20 & 10 & 16.66 & & 25 & 37 & 20.6 \\
\hline Two week & 9 & 15 & 9 & 15 & 18 & 30 & 36 & 19.4 \\
\hline Three week & 14 & 23.33 & 9 & 15 & 11 & 18.33 & 34 & 18.9 \\
\hline Until Incubation & 25 & 41.67 & 32 & 53.33 & 16 & 26.66 & 73 & 41.1 \\
\hline $\mathrm{X}^{2}$ value/p value & & & & & & $12.64 /$ & 0.05 & \\
\hline \multicolumn{9}{|c|}{ (II) Do you select eggs before incubation } \\
\hline Yes & 44 & 73.33 & 48 & 80 & 42 & 70 & 134 & 74.4 \\
\hline No & 16 & 26.66 & 12 & 20 & 18 & 30 & 46 & 25.6 \\
\hline $\mathrm{X}^{2}$ value/p value & & & & & & $54 / 0.44$ & & \\
\hline \multicolumn{9}{|c|}{ (III) Criteria of egg selection } \\
\hline Size of the egg & 5 & 11.36 & 2 & 4.17 & 3 & 7.14 & 10 & 7.5 \\
\hline Shape of egg & 11 & 25 & 9 & 18.75 & 9 & 21.43 & 29 & 21.6 \\
\hline Cleanness egg & 3 & 6.82 & 7 & 14.58 & 5 & 11.91 & 15 & 11.2 \\
\hline Absence of Cracks & 25 & 56.82 & 30 & 62.5 & & 59.52 & 80 & 59.7 \\
\hline $\mathrm{X}^{2}$ value/p value & & & & & & $48 / 0.278$ & & \\
\hline \multicolumn{9}{|c|}{ (IV) Methods used for incubation and rearing of chickens } \\
\hline By natural & 58 & 96.66 & 56 & 93.3 & 60 & 100 & 174 & 96.7 \\
\hline By box Brooder & 2 & 3.33 & 4 & 6.66 & - & - & 6 & 3.3 \\
\hline $\mathrm{X}^{2}$ value $/ \mathrm{p}$ value & & & & & & $14 / 0.12$ & & \\
\hline \multicolumn{9}{|c|}{ (V) Materials used during incubation } \\
\hline Clay pot with straw & 22 & 37.94 & 20 & 35.71 & & 20 & 54 & 31.03 \\
\hline Mud container with straw & 11 & 18.96 & 20 & 35.71 & & 23.33 & 45 & 25.86 \\
\hline Wooden made with straw & 4 & 6.89 & 11 & 19.64 & 2 & 3.33 & 17 & 9.77 \\
\hline Plastic material & 9 & 15.52 & 3 & 5.36 & 6 & 10 & 18 & 10.34 \\
\hline Under holes with sand & 12 & 20.68 & 2 & 3.57 & & 43.33 & 40 & 22.98 \\
\hline $\mathrm{X}^{2}$ value $/ \mathrm{p}$ value & & & & & & $7 / 0.000$ & & \\
\hline
\end{tabular}

In Highland agro-ecology the order was Clay pot with straw, Under holes with sand, Mud container with straw, Plastic material and Wooden made with straw $(37.94,20.68$, $18.96,15.52$ and $6.89 \%$ farmers, respectively) whereas in Midland order was Clay pot with straw, Mud container with straw, Wooden made with straw, Plastic material, Under holes with sand $(35.71,35.71,19.64,5.36,3.57$ respondents, respectively). Likewise in Lowland agro-ecologies the order of bedding material for incubation was under holes with sand, Mud container with straw, Clay pot with straw, plastic material $(43.33,23.33,20.00$ and $10.00 \%$ of respondents, respectively). These results indicated that farmers were using locally and easily available material for bedding during incubation of eggs.

Mearg, F. E [21] and Markos, S., [26] was reported that clay pots with grasses (straw) bedding, ground with soil/sand/ash/cow dung/chopped grasses /straw/sand filled sack bedding, bin with grasses/straw/cotton seed/sand \& feather of brooding hen/sack sand /clothes/cow dung and straw/ bedding, clothes bedding alternatively were used as egg setting materials in western zone of Tigray.

\subsection{Constraints of Local Chicken Rearing System}

The results of the farmer's rankings of constraints in 
poultry production Table 14 showed that disease, predator and feed shortage were the major economically important constraints for the existing chicken rearing system in all agro-ecology. The indication values for disease, predator and feed shortage were $0.306,0.391$ and 0.303 in high-land; $0.346,0.308$ and 0.346 in mid-land; and 0.392, 0.300 and 0.308 in low-land agro-ecologies, respectively. Majority of respondents ranked diseases as the first chicken rearing constraint in mid-land and low-lands but in high-land predators were ranked first constraint by the respondents.
Constraints were not different from those reported by others in Ethiopia such as Solomon, D., [27] who reported that the main constraint of traditional chicken production system was disease. In other study Hassen, H., [19] who reported that diseases and predators were the first and the second major factors that causes loss of chicken in Northwest Ethiopia. Addisu H. [4] also identified as diseases was the first ranked chicken production constraint in Tach Armachiho and Quara district.

Table 14. The Major Constraints in Poultry Production Agro-ecologies.

\begin{tabular}{|c|c|c|c|c|c|c|c|c|c|c|c|c|}
\hline \multirow{2}{*}{ Variables } & \multicolumn{4}{|c|}{ Highland } & \multicolumn{4}{|c|}{ Midland } & \multicolumn{4}{|c|}{ Lowland } \\
\hline & R1 & $\mathbf{R 2}$ & $\mathbf{R 3}$ & I & R1 & $\mathbf{R 2}$ & R3 & I & R1 & $\mathbf{R 2}$ & $\mathbf{R 3}$ & I \\
\hline Disease & 30 & 21 & 9 & 0.306 & 20 & 25 & 10 & 0.346 & 15 & 18 & 27 & 0.392 \\
\hline Predator & 10 & 29 & 21 & 0.391 & 25 & 25 & 10 & 0.308 & 23 & 12 & 18 & 0.30 \\
\hline Feed shortage & 20 & 10 & 30 & 0.303 & 25 & 10 & 40 & 0.346 & 22 & 30 & 15 & 0.308 \\
\hline
\end{tabular}

\subsection{Reproductive Performance of Local Chicken}

The least square mean of various production and reproduction traits (mean age at first service for cockerel in month, age at first egg laying of hen in month, number of clutch per year of local chicken, number of egg per clutch of local chicken, length of clutch in days for local chicken, total eggs per year of local chicken, interval between two consecutive broody periods, number of egg incubate for hatching per year and number of egg set to broody hen) of local chicken populations in the study area was presented in Table 15.

The age at first service of cockerels was 5.23, 5.22 and 5.20 months in Highland. Midland and Low land agroecologies, respectively. The differences among the agroecologies were non-significant. Similarly the age at first laying of egg in hen were 5.92, 5.74, and 5.67 in Highland, Midland and Lowland agro-ecologies, respectively. The differences among the three agro-ecologies were significant $(p<0.001)$. The pair wise comparison of means showed significant differences between Highland-Midland and Highland-Lowland pairs.

This result was in line with the report of Mearg, F. E [21] overall mean age at first mating of male chickens and the age at first egg of female chickens were 5.29 and 5.96 months in central Tigray And smaller than with the report of [20] in which mean age of sexual maturity of indigenous chicken in Fogera district was $23.48 \pm 0.1$ and $23.6 \pm 0.11$ weeks for male and female respectively.

The overall mean number of clutches per hen per year of local chicken ecotypes were $4.29 \pm 0.031$ with $4.36 \pm 0.05$ in high-land, $4.27 \pm 0.04$ in mid-land and $4.26 \pm 0.03$ in low-land agro-ecology respectively. The mean showed that agroecologies had significant influence on mean number of clutches per hen per year $(p<0.023)$. The differences between Highland:-Midland and Highland-Lowland agro-ecologies were significant.

This result was in line with the findings of Markos, S., [26] who reported that the overall mean number of clutches per hen per year of local chicken ecotypes in western zone of Tigray was 4.42 and Mearg, F. E [21] who reported that overall mean number of clutches per hen per year of local chicken ecotypes was 4.58 in central Tigray. The overall mean number of egg per clutch of local chicken were $14.44 \pm 0.12$ with averages in high-land $14.71 \pm 0.20$, in midland $14.38 \pm 0.25$ and in low-land $14.23 \pm 0.12$ agro-ecology the mean showed that agro-ecologies did not affect this trait.

Table 15. Management of Some Reproductive and Productive Performance of Local Hens Recalled by Respondents of the Study Areas (Mean \pm SE).

\begin{tabular}{|c|c|c|c|c|c|}
\hline \multicolumn{5}{|l|}{ Agro ecology } & \multirow{2}{*}{$\begin{array}{l}\mathbf{P} \\
\text { Value }\end{array}$} \\
\hline Variable & Highland & Midland & Lowland & over all & \\
\hline Age at 1st service for cockerel (month) & $5.23 \pm 0.04$ & $5.22 \pm 0.03$ & $5.20 \pm 0.05$ & $5.21 \pm 0.03$ & 0.94 \\
\hline Age at 1 st egg laying of hen (month) & $5.92 \pm 0.04^{\mathrm{a}}$ & $5.74 \pm 0.05^{\mathrm{b}}$ & $5.67 \pm 0.06^{\mathrm{b}}$ & $5.77 \pm 0.03$ & 0.001 \\
\hline Number of egg per clutch of local chicken & $14.71 \pm 0.20$ & $14.38 \pm 0.25$ & $14.23 \pm 0.17$ & $14.4 \overline{4} \pm 0.12$ & 0.247 \\
\hline Length of clutch in days for local chicken & $15.16 \pm 0.27^{\mathrm{a}}$ & $14.40 \pm 0.24^{\mathrm{ab}}$ & $13.71 \pm 0.23^{\mathrm{b}}$ & $14.42 \pm 0.15$ & 0.04 \\
\hline Total eggs per year of local chicken & $63.18 \pm 0.81$ & $62.21 \pm 0.99$ & $60.08 \pm 1.04$ & $61.82 \pm 0.55$ & 0.060 \\
\hline Interval B/NTwo consecutive broody period & $2.96 \pm 0.12$ & $2.82 \pm 0.11$ & $2.78 \pm 0.08$ & $2.86 \pm 0.08$ & 0.15 \\
\hline Times egg incubate for hatching per year & $2.78 \pm 0.08$ & $2.80 \pm 0.10$ & $3.03 \pm 0.09$ & $2.87 \pm 0.05$ & 0.147 \\
\hline Average egg set to broody hen & $13.58 \pm 0.16^{\mathrm{a}}$ & $12.50 \pm 0.3 \mathrm{ab}$ & $10.20 \pm 0.23^{\mathrm{b}}$ & $12.09 \pm 0.17$ & 0.000 \\
\hline
\end{tabular}

The present result showed in Table 15, a number of egg per clutch was smaller as compared with findings of Mearg, F. E [21] who reported 15.20 eggs/clutch in central Tigray; Tadelle, D., [28] who reported 17.7 eggs/ clutch in five agroecology zones of Ethiopia; and Bogale K., [20] reported 16.6 eggs/clutch in Fogera district. However, present results were higher than those reported by Meseret, M., [7] and Addisu H., [4], in which the mean egg number laid per clutch per hen of local chickens in Gomma wereda and North Wollo Zone were 12.92 and 12.64 , respectively. 
The overall mean length of clutch in days for cycle of local chicken were $15.16 \pm 0.27,14.40 \pm 0.24$ and $13.71 \pm 0.23$ days in high-land, mid-land and low-land areas, respectively. The overall mean length of clutch in days was 14.42 days. The mean showed that agro-ecologies had significant $(\mathrm{P}<0.05)$ influence on length of clutch in days for cycle. There was a significant difference between high-land- low-land agroecologies.

The overall total number of eggs per year per hen in highland, mid-land, low-land and overall average was $63.18 \pm 0.81,62.21 \pm 0.99,60.08 \pm 1.04$ and $61.82 \pm 0.55$ of eggs, respectively. The least square mean revealed that agroecologies had non-significant effect on total number of eggs per year per hen. This result was similar with reports of Fisseha, M., [3] and Mekonnen, G., [18] who reported that the mean annual egg yield per hen of indigenous chickens in Bure district and Wonsho district were 60 eggs and 62.95 eggs.

The interval between two consecutive broody periods was not affected by agro-ecologies. The mean interval between two consecutive broody periods was 2.96, 2.82, 2.78, 2.86 months in Highland, Midland, Lowland and overall, respectively, in the present study. The number of egg incubated for hatching per year was not affected by agroecologies significantly. The mean number of egg incubated for hatching per year were $2.78 \pm 0.08,2.80 \pm 0.10$ and $3.03 \pm 0.09$ in high-land, mid-land and low-land agro-ecology, respectively.

The number of eggs set to broody hen was influenced highly significant $(\mathrm{P}<0.0001)$ by agro-ecologies. The number of eggs set to broody hen were $13.58 \pm 0.16$, $12.50 \pm 0.30,10.20 \pm 0.23$, and $12.09 \pm 0.17$ in high-land, midland, low-land and overall mean, respectively. This result was higher than Mearg, [21], who reported that the number of eggs incubated in midland and highland agro-ecologies were 11.4 and 11.4 , respectively in central Tigray.

\subsection{Breeding Practice of Local Chicken}

The results on breeding practices were presented in Table 16. The study showed that breeding practices were followed by $71.7,63.3 \%$ respondent farmers in Highland and Midland agro-ecologies, respectively, whereas no breeding practice was followed in Lowland as per report of $51.66 \%$ respondents. The majority, more than $75 \%$, of respondent farmers reported that both male and female birds were selected as future parents and the proportion of farmers exercising this selection were $90.00,83.33$, and $78.33 \%$ in Highland, Midland and Lowland, agro-ecologies, respectively. Nigussie, D., [29] reported that beside other quantitative traits, morphologic traits such as plumage color and comb type have significant economic values.

The mating system showed that mating was uncontrolled in majority of birds as stated by $88.3,81.66$, and $83.33 \%$ of respondents in Highland, Midland and Lowland agroecologies, respectively. This result is nearly similar with Addisu H., [4] who reported that about $10.79 \%$ of respondents control mating system. But this result is not in line with the report of Nigussie, D., [29] who reported that breeding is completely uncontrolled and replacement stock produced through natural incubation using broody hens in different parts of Ethiopia. The possible reason for high prevalence of uncontrolled mating might be described to scavenging nature village chicken management.

The respondents who allow controlled mating in their flock stated that control mating was made possible by (i) culling unproductive poultry, (ii) culling for unwanted colour, (iii) retaining best cock, The study further showed that retaining best cock and culling for unwanted colour methods were followed by more number of respondents $(42.8,42.8 \%$ respondents in Highland; 57.14, 36.36\% respondents in Midland; and 50.0, 30.0\% respondent in Lowland agroecologies). Chickens that were not retained for breeding purposes were culled through sale $(42.86,54.6,50.00 \%$ of respondents in Highland, Midland and Lowland agroecologies, respectively); home Consumption (27.27, 28.57, $20.00 \%$ of respondents in Highland, Midland and Lowland agro-ecologies, respectively); and sales \& consumption (28.57, 18.2, 30.00\% of respondents in Highland, Midland and Lowland agro-ecologies, respectively).

This result was similar with the findings of Addisu H., [4] who reported that slaughtering (53.27\%), selling (41.18\%) and devour or sell eggs of unwanted hens $(5.56 \%)$ were a major means of culling less productive chicken from the flock in North Gonder.

Table 16. Breeding Practice of Chicken in the Study Area.

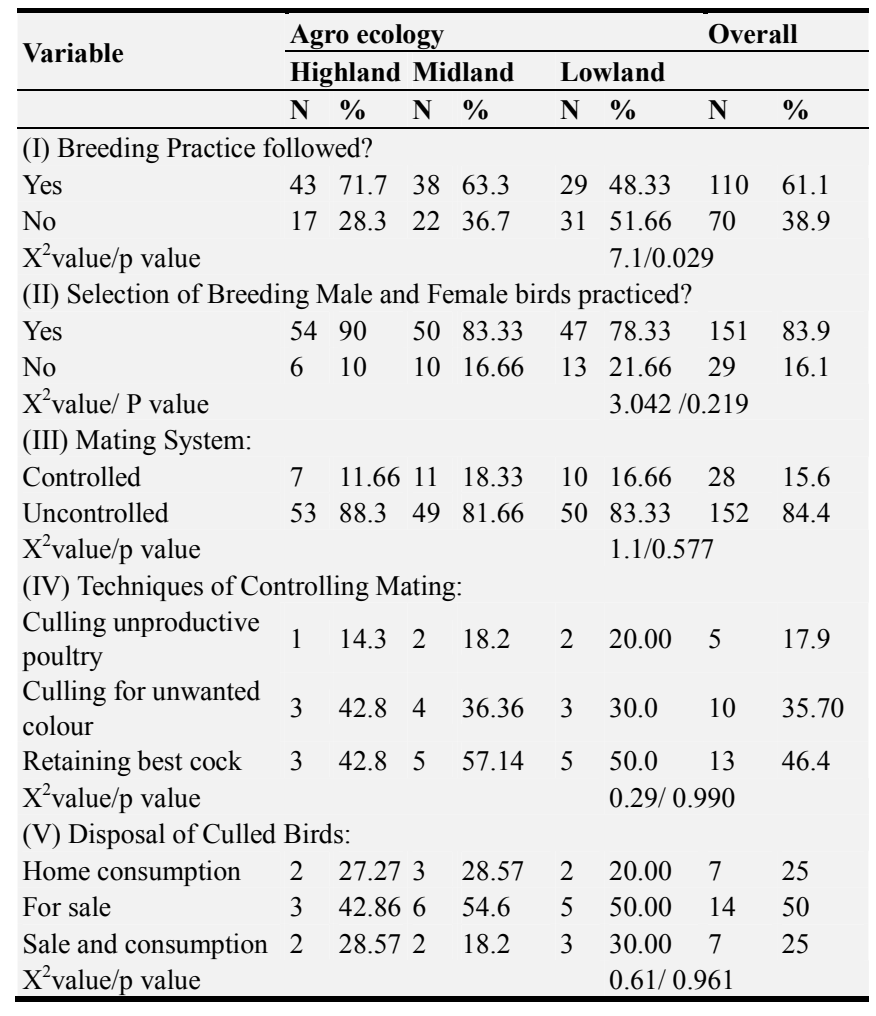

\subsection{Farmer's Ranking of Selection Criteria for Hens and Cocks}

The farmer's ranking of selection criteria for selection of male and female birds as future parents is presented in Table 
17. The results showed that respondent farmers ranked egg number and size, growth rate, plumage colour as first three criteria, in descending order, for selection of hens in Highland (with indices values of $0.383,0.134$ and 0.097 , respectively); egg number and size, growth rate disease tolerance as first three criteria, in descending order, in Midland (with indices values of $0.348,0.190,0.168$, respectively); and egg number \& size, plumage colour, growth rate as first three criteria, in descending order, in Lowland (with indices values of 0.372 , 0.153. 0.137 , respectively). The egg number together with size was ranked as number of criteria for hen selection in all agroecologies and this showed the importance egg number and egg size. The possible reason might be that higher number of eggs together with bigger size ensures more economic return to the farmer.

Perusal of table 17 showed that disease tolerance of cocks was number one selection criteria in all agro-ecologies (with index values of $0.289,0.314$, and 0.274 in Highland, Midland and Lowland, respectively). However the agro-ecologies showed differences in the next two selection criteria for cocks. In Highland plunage colour, fertility, growth rate were number two, three and four cock selection criteria (Index values of $0.179,0.159,0.125$, respectively); in Midland plumage colour, growth rate, comb type were two, three and four cock selection criteria (index values of $0.189,0.189$, 0,131, respectively); and in Lowland growth rate, plumage colour, comb type were two, three, four cock selection criteria $(0.279,0.162,0.127$, respectively).

This result of Abdelqader, A., [22] also reported that the most important traits of farmers in Jordan were growth rate, disease tolerance, egg yield, body size and fertility, The present finding were comparable with reports of Addisu H., [4] and Mearg, F. E. [21].

Table 17. Farmer's Ranking of Selection Criteria's For Hen and Cocks.

\begin{tabular}{|c|c|c|c|c|c|c|c|c|c|c|c|c|}
\hline \multirow{3}{*}{ Variables } & \multicolumn{12}{|c|}{ Agro-ecologies } \\
\hline & \multicolumn{4}{|c|}{ Highland } & \multicolumn{4}{|c|}{ Midland } & \multicolumn{4}{|c|}{ Lowland } \\
\hline & R1 & R2 & R3 & I & R1 & $\mathbf{R 2}$ & R3 & I & R1 & $\mathbf{R 2}$ & R3 & $\mathbf{I}$ \\
\hline \multicolumn{13}{|l|}{ (I) Hens } \\
\hline Egg number \& size & 25 & 20 & 23 & 0.383 & 24 & 20 & 16 & 0.348 & 24 & 20 & 22 & 0.372 \\
\hline Growth rate & 13 & 3 & 3 & 0.134 & 10 & 15 & 10 & 0.190 & 11 & 5 & 3 & 0.127 \\
\hline Hatchability & 1 & 5 & 4 & 0.047 & 1 & 5 & 3 & 0.043 & 3 & 0 & 8 & 0.047 \\
\hline Mothering ability & 2 & 6 & 4 & 0.062 & 2 & 0 & 4 & 0.027 & 2 & 2 & 6 & 0.044 \\
\hline Brooding & 3 & 8 & 2 & 0.075 & 2 & 2 & 2 & 0.032 & 8 & 5 & 7 & 0.114 \\
\hline Disease Tolerance & 2 & 7 & 10 & 0.084 & 7 & 13 & 15 & 0.168 & 4 & 4 & 3 & 0.063 \\
\hline Plumage colour & 8 & 3 & 5 & 0.097 & 10 & 3 & 7 & 0.117 & 5 & 16 & 8 & 0.153 \\
\hline Good scavenging & 5 & 2 & 4 & 0.063 & 2 & 2 & 3 & 0.035 & 3 & 5 & 1 & 0.056 \\
\hline $\begin{array}{l}\text { Fighting ability } \\
\text { (II) Cocks }\end{array}$ & 1 & 6 & 5 & 0.055 & 3 & 1 & 2 & 0.035 & 0 & 3 & 2 & 0.024 \\
\hline Disease tolerance & 8 & 28 & 25 & 0.289 & 23 & 13 & 18 & 0.314 & 12 & 18 & 25 & 0.274 \\
\hline Growth rate & 6 & 7 & 13 & 0.125 & 15 & 10 & 3 & 0.189 & 20 & 17 & 5 & 0.279 \\
\hline Comb type & 10 & 2 & 5 & 0.107 & 5 & 15 & 2 & 0.131 & 9 & 3 & 12 & 0.127 \\
\hline Fighting ability & 7 & 5 & 2 & 0.092 & 3 & 6 & 4 & 0.069 & 1 & 5 & 9 & 0.062 \\
\hline Plumage colour & 19 & 4 & 0 & 0.179 & 8 & 12 & 20 & 0.189 & 16 & 4 & 1 & 0.162 \\
\hline Fertility & 7 & 12 & 13 & 0.159 & 4 & 4 & 10 & 0.083 & 0 & 7 & 7 & 0.059 \\
\hline Temperament & 4 & 2 & 2 & 0.049 & 2 & 0 & 3 & 0.025 & 0 & 6 & 1 & 0.037 \\
\hline
\end{tabular}

\subsection{Farmer's Selection and Culling Practices}

The result on selection and culling practices in the study areas was presented in Table 18. The study on ownership of breeding cock showed that $68.33,63.33,66.66$ and $66.11 \%$ of respondent farmers were rearing their own breeding cocks in Highland, Midland, Low land agro-ecologies and overall, respectively. This indicated that more than $50 \%$ farmers rear own breeding cocks and thus effective population size would be good translating in low inbreeding. The remaining proportions of respondents did not own breeding cock.

The results further showed that respondent farmers not owning their breeding cock managed breeding of their hens by either shared with neighbors or communal cock or purchased from market or purchased from extension agencies. However, majority of these respondents (47.37, $50.00,50.00$ and $49.2 \%$ in Highland, Midland, Lowland agro-ecologies and overall, respectively) managed mating of hens by shared with neighbors cocks.
This result was in agreement with the report of Nigussie, D., [29] who reported that from $31 \%$ to $55.6 \%$ of the farmers of different regions of Ethiopia did not own breeding males. Most of them shared breeding males with neighbors. The study of types/breeds of poultry in the study areas showed that more than $70 \%$ of respondent farmers reared local type of cocks. The proportions of respondents rearing local cocks were 92.67, 73.7, and $85.00 \%$ in Highland, Midland, Lowland agro-ecologies, respectively. A very small proportion of respondents reared chicks of exotic breeds $(0.0$, 5.26, and $4.00 \%$ in Highland, Midland and Lowland agroecologies, respectively).

The present study revealed that culling was practiced by all $(100 \%)$ respondents in all agro-ecologies (AEGs). The respondents stated a number of reasons for culling and these were old age, low production, unwanted plumage, sickness and bad temperament. Out of these reasons results showed, based on respondent farmers interview, that sickness was main reason for culling in Highland and Lowland agroecologies $(35.00$ and $31.66 \%$, respectively) whereas 
unwanted plumage colour was main reason $(31.67 \%)$ of culling in Midland agro-ecologies.

The overall figures showed that proportion of respondents attributing culling to sickness, low production; unwanted plumage, bad temperament and old age were 29.4, 23.3, 22.2, 14.4 and $10.6 \%$, respectively. This finding was in line with Mearg, F. E. [21] who stated that in high-land and mid-land agro ecologies low production of chicken, old age, unwanted plumage color, sickness, bad temperament of hens and cocks and low hatchability were the main culling criteria.

Table 18. Farmers Selection and Culling Practices.

\begin{tabular}{|c|c|c|c|c|c|c|c|c|}
\hline \multirow{3}{*}{ Variables } & \multicolumn{8}{|c|}{ Agro-ecologies } \\
\hline & \multicolumn{2}{|c|}{ High-land } & \multicolumn{2}{|c|}{ Mid-land } & \multicolumn{2}{|c|}{ Low-land } & \multicolumn{2}{|c|}{ Overall } \\
\hline & $\mathbf{N}$ & $\%$ & $\mathbf{N}$ & $\%$ & $\mathbf{N}$ & $\%$ & $\mathbf{N}$ & $\%$ \\
\hline \multicolumn{9}{|c|}{ (I) Ownership of breeding cock } \\
\hline Rearing own cock & 41 & 68.33 & 38 & 63.33 & 40 & 66.66 & 119 & 66.11 \\
\hline Not rear own cock & 19 & 31.66 & 22 & 36.66 & 20 & 33.33 & 61 & 33.89 \\
\hline $\mathrm{X}^{2}$ value/ $\mathrm{P}$ value & & & & & & $0.347 /($ & 0.841 & \\
\hline \multicolumn{9}{|c|}{ (II) Source of breeding cock of farmers not owning cock } \\
\hline $\begin{array}{l}\text { Shared with Neigh- } \\
\text { bours }\end{array}$ & 9 & 47.37 & 11 & 50.00 & 10 & 50.00 & 30 & 49.2 \\
\hline Communal Cock & 5 & 26.32 & 3 & 13.6 & 7 & 35.00 & 15 & 24.6 \\
\hline Purchased from Market & 3 & 15.79 & 6 & 27.27 & 3 & 15.00 & 12 & 19.7 \\
\hline $\begin{array}{l}\text { Purchased from } \\
\text { Extension Agencies }\end{array}$ & 2 & 10.52 & 2 & 9.09 & - & - & 4 & 6.6 \\
\hline \multicolumn{9}{|c|}{ (III) Breed cocks of the Poultry in study area } \\
\hline Local Types & 38 & 92.67 & 28 & 73.7 & 34 & 85.00 & 100 & 84.00 \\
\hline Exotic breeds & - & - & 2 & 5.26 & 2 & 5 & 4.00 & 3.4 \\
\hline Crossbreds & 3 & 7.32 & 8 & 21.1 & 4 & 10 & 15.0 & 12.6 \\
\hline $\begin{array}{l}\mathrm{X}^{2} \text { value/ } \mathrm{P} \text { value } \\
\text { (IV) culling Practice }\end{array}$ & & & & & & $6.24 / 0$. & & \\
\hline Yes & 60 & 100 & 60 & 100 & 60 & 100 & 180 & 100 \\
\hline \multicolumn{9}{|l|}{ (V) Reasons for culling } \\
\hline Old age & 3 & 5 & 5 & 8.33 & 11 & 18.33 & 19 & 10.6 \\
\hline Low production & 15 & 25 & 17 & 28.3 & 10 & 16.66 & 42 & 23.3 \\
\hline Unwanted plumage & 10 & 16.66 & 19 & 31.67 & 11 & 18.33 & 40 & 22.2 \\
\hline Sickness & 21 & 35 & 13 & 21.66 & 19 & 31.66 & 53 & 29.4 \\
\hline Bad temperament & 11 & 18.3 & 6 & 10 & 9 & 15 & 26 & 14.4 \\
\hline $\mathrm{X}^{2}$ value/ $\mathrm{P}$ value & & & & & & $14.40 /$ & 0.072 & \\
\hline
\end{tabular}

\subsection{Effective Population Size and Coefficient of Inbreeding}

The overall mean effective population size $(\mathrm{Ne})$ and the rate of inbreeding coefficient $(\Delta \mathrm{F})$ calculated for the indigenous chicken flock of the study area was 3.55 and 0.14 , respectively Table 19 . The effective population size $(\mathrm{Ne})$ was 3.71, 3.65 and 3.29 in high-land, mid-land and low-land agro-ecologies of the study areas. The possible reasons for low $\mathrm{Ne}$ might be a low number of male and female birds in general but a very low number of males in particular. Low $\mathrm{Ne}$ directly affects coefficient of in breeding.

The rates of inbreeding coefficient $(\Delta \mathrm{F})$, in the free-range scavenging chicken population, estimated were $0.13,0.14$, and 0.15 in Highland, Midland and Lowland agro-ecologies, respectively. The inbreeding coefficient was not significantly different across the three agro-ecologies. The possible reason of high inbreeding might be ascribed to low effective population size.

The present result were higher in terms of inbreeding than the reports of Mearg, F. E. [21, Feyera, B.30] and Getachew, B., [31] who stated that $\mathrm{Ne}$ and inbreeding were 3.99 and 0.113 in central Tigray; and 4.41 and 0.12 in Western Oromia; and 4.13 and 0.122 Southern Tigray, respectively. However the present estimates of inbreeding were lower that the estimates of 3.9 and 0.195 in Fogera district by Bogale, (2008); and 2.66 and 0.18 in Jimma zone and 3.37 and 0.15 in Bench-maij zone by Hailemikael, N., [32].

Table 19. Effective Population Size and Coefficient of Inbreeding in the Study Areas.

\begin{tabular}{lllll}
\hline \multirow{2}{*}{ Variable } & \multicolumn{4}{l}{ Agro-ecologies } \\
\cline { 2 - 5 } & Highland & Midland & Lowland & Overall \\
\hline $\mathrm{Nm}$ & 1.17 & 1.21 & 0.98 & 1.12 \\
$\mathrm{Nf}$ & 4.50 & 5.05 & 5.12 & 4.89 \\
$\mathrm{Ne}$ & 3.71 & 3.65 & 3.29 & 3.55 \\
$\Delta \mathrm{F}$ & 0.13 & 0.14 & 0.15 & 0.14 \\
\hline
\end{tabular}

Nm: Number of breeding male, Nf: Number of breeding female, Ne: Effective Population Size and $\Delta \mathrm{F}$ : Inbreeding Coefficient.

\section{Conclusion and Recommendation}

In Ethiopia, the agricultural sector is a corner stone of the economic and social life of the people since they are used for generation of extra cash incomes, provision of animal protein and religious/cultural considerations. Understanding the situation of poultry rearing was crucial for improvement of poultry products and to design poultry breeding strategy. Generally chicken rearing system in the study area was mixed with crop- livestock production system using traditional management of indigenous chickens. The presences of various predators and diseases prevalence were two major economic important of chicken rearing constraints. The study also showed that wide variations of traits considered among the indigenous chickens in the study area.

i. Creation of adequate awareness should be carried out about chicken management system for the improvement of chicken products.

ii. Poultry breeding policy which focused on selection and trait preference should be designed.

iii. Government, research and developmental organizations should give attention to village poultry sector and its development.

iv. Government should train community chicken vaccinators to provide wide spread vaccination against major poultry diseases.

\section{Acknowledgements}

First and above all I would like to thank the almighty God with His Mother St. Virgin Mary for his willingness to reach at this stage; without his assistance nothing would be happened. He has unreservedly offered me during the study and all the time. I would like to express my deepest and sincere appreciation to my respected major advisor Manzoor Ahmed Kirmani (Prof.), for his unreserved advice, guidance and comments from proposal write up to submission of the final thesis write up the initial of conception to the end of this 
work are highly appreciated. I am very grateful to my coadvisor Meseret Molla (ASS,rof) for her valuable comments, advice, criticism make this work complete. She shaped me to be more analytical in many aspects. Thank you very much my major advisor Manzoor Ahmed Kirmani (Prof.) and Meseret Molla (Ass prof).

I would like to express my deepest gratitude and appreciation to Ministry of Education for fully sponsoring my study and research work and Department Graduate Committee (DGC) of Animal Sciences and the School of Graduate Studies of Jimma University for their conducive learning program and provision of various services. I also wish to express my thanks to agricultural office of Awi zone, all developmental agent (DA), kebele administrations and farmers of all the study districts for their kindness, encouragement and help during data collection in who responded to my numerous questions with patience.

\section{References}

[1] FAOSTAT Database, 2012. Retrieved October10, 2014, from http://faostat.fao.org/faostat/,FAO, Rome.

[2] CSA (central statistical agency). 2016/17[2009 E. C.] livestock and livestock characteristics (private peasant holdings); agricultural sample survey volume 2, federal democratic republic of Ethiopia, Addis Ababa, Ethiopia.

[3] Fisseha, M., 2010. Indigenous chicken production and marketing systems in Ethiopia: Characteristics and opportunities for market-oriented development (Vol. 24). ILRI (aka ILCA and ILRAD).

[4] Addisu H., 2012. Phenotypic Characterization of Indigenous Chicken Ecotypes in NorthWollo Amhara Regional State. MSc Thesis, Wollo University, Wollo, Ethiopia.

[5] Gueye, E. F., 2009. The role of networks in information dissemination to family poultry farmers. World's Poultry Science Journal, 65(1); 115-124.

[6] Besbes, B., Thieme, O., Rota, A., Guèye, E. F., Alders, R. G., Sandilands, V. and Hocking, 2012. Technology and programmes for sustainable improvement of village poultry production. Alternative systems for poultry: Health, welfare and productivity; 110-127.

[7] Meseret, M., 2010. Characterization of village chicken production and marketing system in Gomma Wereda, Jimma Zone, Ethiopia (Doctoral dissertation, Jimma University).

[8] Moreki, J. C., Dikeme, R. and Poroga, B., 2010. The role of village poultry in food security and HIV/AIDS mitigation in Chobe District of Botswana. Livestock Research for Rural Development, 22 (3); 1-7.

[9] Soelkner J, Nakimbugwe H and Zarate A V. 2002. Analysis of determinants for success and failure of village breeding programmes. In: Proceedings of the Sixth World Congress on Genetics Applied to Livestock Production, Australia. 25:273-280.

[10] Cochran, W. G. 1963. Sampling Techniques, 2nd Ed., New York: John Wiley and Sons, Inc

[11] SPSS 2013. Software Package for Social Sciences for
Window.

[12] Musa, L. M-A., Peters, K. J. and Ahmed, M-K. A. 2006. On farm characterization of Butana and Kenana cattle breed production systems in Sudan.

[13] Falconer, D. S. and Mckay, T. F. C. 1996. Introduction to quantitative genetics. $4^{\text {th }}$ edition.

[14] Halima, H., Neser, F. W. C., van Marle-Koster, E. and De Kock, A., 2007. Phenotypic variation of native chicken populations in northwest Ethiopia. Tropical animal healthand production, 39 (7), pp. 507-513.

[15] Bekele, N., Urge, M., Ameha, N. and Fereja, G. B., 2014. Study of production practices, and productivity of village chicken in Chelliya District, Ethiopia. Science, Technology and Arts Research Journal, 4(3), 117-122.

[16] Shishay Markos, Berhanu Belay and Tadelle Dessie. 2014. Incubation and Brooding Practices of Local Chicken Producers in Ethiopia: The Case of Western Zone of Tigray. Journal of Biology, Agriculture and Healthcare. Vol. 4, No. 25.

[17] Alem, A. T., Yayneshet, G. T. and Aklilu, A. H., 2014. Socioeconomic characteristics of poultry production in lowland and midland agro-ecological zones of central Tigray, Ethiopia. International Journal of Livestock Production, 5 (4); 71-80.

[18] Mekonnen, G., 2007. Characterization of the Small Holder Poultry Production and Marketing System of Dale, Wonshoa Ndola Abaya Woredaof SNNPRS, Ethiopia. MSc Thesis, Hawassa University, Hawassa, Ethiopia.

[19] Hassen, H., 2007. Phonotypic and genetic characterization of indigenous chicken populations in Northwest Ethiopia PhD Thesis. National and agricultural sciences department of animal Wild life and Grassland Sciences University of the Free State, Bloemfontein, South Africa.

[20] Bogale K., 2008. InSitu Characterization of Local Chicken Eco-Type for Functional Traits and Production System in Fogera District, Amhara Regional State. MSc Thesis Harmaya University, Haramaya, Ethiopia.

[21] Mearg, F. E. A. R. G., 2016. Phenotypic characterization of local chicken ecotypes in the Central Zone of Tigray in northern Ethiopia (M.ScThesis, Jimma University).

[22] Abdelqader, A., Wollny, C. B. A. and Gauly, M., 2007. Characterization of local chicken production systems and their potential under different levels of management practice in Jordan. Tropical Animal Health and Production, 39 (3), 155-164.

[23] Melaku, T. A. and Negassi, A., 2016. On farm Phenotypic Characterization of Indigenous Chicken Population and Their Production System at Wogdi, Borena and Legambo Districts in South Wollo Ethiopia (Doctoral dissertation, Harmaya University).

[24] Emebet, M., Singh, H., Sisaye, T. and Johansson, A. M., 2016. Phenotypic characterization of indigenous chicken population in South West and South part of Ethiopia. Br. J. Poult. Sci, 3 (1), pp. 15-19.

[25] Hunduma, D., Regassa, C., Fufa, D., Andale, B. and Samson, L., 2010. Major constraints and health management of village poultry production in rift valley of Oromia, Ethiopia. Global Veterinaria, 5 (1), pp. 6-10. Kenana cattle breed production systems in Sudan. Livestock Research for Rural Development. $18,56-61$. 
[26] Markos, S., Berhanu, B. and Tadelle, D., 2014. On Farm Performance Evaluation of Three Local Chicken Ecotypes in Western Zone of Tigray, Northern Ethiopia. Performance improvement, 5 (7).

[27] Solomon, D., 2007. Suitability of hay-box brooding technology to rural household poultry production system. Jimma University College of Agriculture and Veterinary Medicine, Jimma, Ethiopia.

[28] Tadelle, D., T. Million, and Alemu Yami \& K. J. Peters 2003. Village chicken production systems in Ethiopia: Use patterns $\&$ performance evaluation and chicken products \&socioeconomic functions of chicken. Livestock Research for Rural Development 15 (1).

[29] Nigussie, D., 2011. Breeding programs for indigenous chicken in Ethiopia: analysis of diversity in production systems and chicken populations. PhDDissertation, Wageningen University, the Netherlands.

[30] Feyera, B. E., 2016. Phenotypic Characterization of Indigenous Chicken and Their Production System in Gobu Sayo, Bako Tibe and Danno Districts of Western Oromia, Ethiopia(Doctoral dissertation, Harmaya University).

[31] Getachew, B., Kefelegn, K. and Negassi, A., 2014. On-farm Phenotypic Characterization of Indigenous Chicken and their Production System in Bench Maji Zone, South Western Ethiopia. Science, Technology and Arts Research Journal, 4 (1), 68-73.

[32] Hailemikael, N., 2013. On-farm phenotypic characterization of indigenous chicken and chicken production systems in southern zone of Tigray, northern Ethiopia. 